\title{
Varieties of Capitalism and Institutional Complementarities in the Political Economy: An Empirical Analysis
}

\author{
PETER A. HALL AND DANIEL W. GINGERICH*
}

\begin{abstract}
This article provides a statistical analysis of core contentions of the 'varieties of capitalism' perspective on comparative capitalism. The authors construct indices to assess whether patterns of co-ordination in the OECD economies conform to the predictions of the theory and compare the correspondence of institutions across subspheres of the political economy. They test whether institutional complementarities occur across these subspheres by estimating the impact of complementarities in labour relations and corporate governance on growth rates. To assess the durability of varieties of capitalism, they report on the extent of institutional change in the 1980s and 1990s. Powerful interaction effects across institutions in the subspheres of the political economy must be considered if assessments of the economic impact of institutional reform in any one sphere are to be accurate.
\end{abstract}

The field of comparative political economy has been interested for many years in understanding how differences in the organization of national political economies condition aggregate economic performance. Behind such inquiries lies the intuition that more than one economic model can deliver economic success. But what are the central features that distinguish the operation of one political economy from another, and how should countries be categorized along these dimensions of difference?

For the developed economies, the answers usually given to these questions in each era have corresponded to the principal challenges confronting those economies. During the 1960s, when economic modernization was high on the agenda, efforts to identify distinctive types of capitalism emphasized variation in the character of state intervention into the economy. ${ }^{1}$ When inflation rose to new heights during the 1970 s, the emphasis shifted to the contributions of neo-corporatism to wage and price moderation. ${ }^{2}$ In recent years, scholars have been seeking approaches salient to an era of globalization. ${ }^{3}$

* Department of Government, Harvard University and Woodrow Wilson Department of Politics, University of Virginia (email: phall@fas.harvard.edu). The authors wish to record their gratitude to Alexander Kuo and Stanislav Markus for efficient research assistance and to the John D. and Catherine T. MacArthur Foundation for a grant to Hall for research and writing. For helpful comments, they wish to thank James Alt, Bruno Amable, Moreno Bertoldi, Robert Boyer, Colin Crouch, Ekkehard Ernst, Peter Gourevitch, Torben Iversen, Bruce Kogut, Jonas Pontusson, Marino Regini, David Soskice and Wolfgang Streeck.

1 Andrew Shonfield, Modern Capitalism (Oxford: Oxford University Press, 1969); Chalmers Johnson, MITI and the Japanese Miracle: The Growth of Industrial Policy 1925-75 (Stanford, Calif.: Stanford University Press, 1982).

${ }^{2}$ Fritz Scharpf, Crisis and Choice in European Social Democracy (Ithaca, N.Y.: Cornell University Press, 1991); Peter J. Katzenstein, Small States in World Markets (Ithaca, N.Y.: Cornell University Press, 1985); Lars Calmfors and John Driffill, 'Centralization of Wage Bargaining', Economic Policy, 6 (1988), 13-61; David Cameron, 'Social Democracy, Corporatism, Labour Quiescence and the Representation of Economic Interest in Advanced Capitalist Society', in John H. Goldthorpe, ed., Order and Conflict in Contemporary Capitalism (New York: Oxford University Press, 1984), pp. 143-78.

${ }^{3}$ Bruno Amable, The Diversity of Modern Capitalism (Oxford: Oxford University Press, 2004); Vivien Schmidt, The Futures of European Capitalism (New York: Oxford University Press, 2002); Colin Crouch 
The object of this analysis is to subject one of the most prominent of these new approaches to a set of empirical tests. We focus on the 'varieties of capitalism' perspective introduced in a volume edited by Hall and Soskice and now widely referenced in the literature. ${ }^{4}$ Applying the new economics of organization to the macroeconomy, this approach distinguishes between capitalist economies by reference to the ways firms and other actors co-ordinate their endeavours. It suggests that nations cluster into identifiable groups based on the extent to which firms rely on market or strategic modes of coordination. From these formulations follow many important contentions about variations in economic performance, comparative institutional advantage, national responses to globalization and comparative public policy.

The varieties-of-capitalism approach is grounded in a rich set of comparative casestudies, but efforts to assess it using statistical analysis on larger numbers of cases are still at an early stage. ${ }^{5}$ Those efforts have been limited partly because we do not yet have good measures for the character of co-ordination, the concept at the heart of the analysis. As a result, the position of many countries within those categories remains ambiguous. We seek indicators for co-ordination that will allow us to test some basic tenets of this approach and that others can use for subsequent assessments.

We are especially interested in one of the core contentions of the varieties-of-capitalism approach, namely, its theory of institutional complementarities in the macroeconomy. One set of institutions is said to be complementary to another when its presence raises the returns available from the other. Economists have identified such complementarities at the level of the firm, where marketing strategies based on customized products, for instance, may be complementary to computer-controlled production processes. ${ }^{6}$ However, Hall and Soskice argue that complementarities, with positive effects on aggregate economic performance, are embedded in institutions across subspheres of the political economy. ${ }^{7}$ This is an important

(F'note continued)

and Wolfgang Streeck, eds, The Political Economy of Modern Capitalism: Mapping Convergence and Diversity (London: Sage, 1997); Suzanne Berger and Ronald Dore, eds, National Diversity and Global Capitalism (Ithaca, N.Y.: Cornell University Press, 1996); Michel Albert, Capitalism Against Capitalism (London: Whurr, 1992).

${ }^{4}$ Peter A. Hall and David Soskice, eds, Varieties of Capitalism: The Institutional Foundations of Comparative Advantage (Oxford: Oxford University Press, 2001); Bob Hancké, Martin Rhodes and Mark Thatcher, eds, Beyond Varieties of Capitalism: Conflict, Contradiction and Complementarities in the European Economy (Oxford: Oxford University Press, 2007); John L. Campbell, John A. Hall and Ove K. Pedersen, National Identity and the Varieties of Capitalism: The Danish Experience (Montreal: McGill University Press, 2006); David Rueda and Jonas Pontusson, 'Wage Inequality and Varieties of Capitalism', World Politics, 52 (2000), 350-83; Herbert Kitschelt, Peter Lange, Gary Marks and John Stephens, eds, Continuity and Change in Contemporary Capitalism (New York: Cambridge University Press, 1999).

${ }^{5}$ For efforts to look at some of its propositions, see Mark Zachary Taylor, 'Empirical Evidence Against Variety of Capitalism's Theory of Technological Innovation', International Organization, 58 (2004), 601-31; Lane Kenworthy, 'Institutional Coherence and Macroeconomic Performance', SocioEconomic Review, 4 (2006), 69-91; Matthew Allen, Lothar Funk and Heinz Tüselman, 'Can Variation in Public Policies Account for Differences in Comparative Advantage?' Journal of Public Policy, 26 (2006), $1-19$.

${ }^{6}$ R. Jaikumar, 'Postindustrial Manufacturing', Harvard Business Review, November-December (1986), 69-76; Paul Milgrom and John Roberts, 'The Economics of Modern Manufacturing, Technology, Strategy and Organization', American Economic Review, 80 (1990), 511-28; Paul Milgrom and John Roberts, Economics, Organization, and Management (Englewood Cliffs, N.J.: Prentice Hall, 1992).

7 See also Masahiko Aoki, 'The Japanese Firm as a System of Attributes: A Survey and Research Agenda', in Masahiko Aoki and Ronald Dore, eds, The Japanese Firm: Sources of Competitive Strength 
contention. If correct, it implies that efforts to reform one sphere of the political economy may yield negative economic results if unaccompanied by parallel reforms in other spheres. It predicts a particular politics of institutional defence.

By subjecting that contention to empirical assessment, we bring together issues typically treated by quite separate literatures. One considers the impact of institutional reform in labour markets, while another considers reform in corporate governance. ${ }^{8}$ However, there is growing evidence of interactions across some spheres of the political economy. ${ }^{9}$ We ask whether the interaction effects postulated by the varieties-of-capitalism approach can be found across the spheres of labour relations and corporate governance.

We begin by developing indices to measure the character of co-ordination in labour relations and corporate governance. We then use these measures to assess the plausibility of the logic used by varieties-of-capitalism analysts to differentiate among developed political economies and the appropriateness of its categories. Turning to the theory's core postulates about the presence of institutional complementarities in the macroeconomy, we ask whether the institutional arrangements it sees as complementary actually yield higher rates of economic growth. Finally, we inquire into the durability of the categories generated by the varieties-of-capitalism literature, by examining patterns of institutional change over the past two decades. Before taking up its core propositions, however, we open with an overview of the varieties-of-capitalism perspective. ${ }^{10}$

(F'note continued)

(Oxford: Clarendon Press, 1994), pp. 11-40; Martin Höpner, 'What Connects Industrial Relations and Corporate Governance? Explaining Institutional Complementarity’, Socio-Economic Review, 3 (2005), 331-58; Glenn Morgan, Richard Whitley and Eli Moen, eds, Changing Capitalisms? Internationalization, Institutional Change and Systems of Economic Organization (Oxford: Oxford University Press, 2005).

${ }^{8}$ Stephen Nickell, 'Unemployment and Labour Market Rigidities, Europe versus North America', Journal of Economic Perspectives, 11 (1997), 55-74; Organization for Economic Cooperation and Development, OECD Jobs Study: Evidence and Explanations; Part II, The Adjustment Potential of the Labour Market (Paris: OECD, 1994); Calmfors and Driffill, 'Centralization of Wage Bargaining'; Wendy Carlin and Colin Mayer, 'How Do Financial Systems Affect Economic Performance?', in Xavier Vives, ed., Corporate Governance: Theoretical and Empirical Perspectives (New York, Cambridge University Press 2000), pp. 137-68; Rafael LaPorta, Florencio Lopez-de-Silanes, Andrei Schleifer and Robert W. Vishny, 'Law and Finance', Journal of Political Economy, 106 (1998), 1113-55.

9 Robert J. Franzese Jr, Macroeconomic Policies of Developed Democracies (New York: Cambridge University Press, 2001); Bruno Amable, Ekkehard Ernst and Stefano Palombarini, 'How Do Financial Markets Affect Industrial Relations: An Institutional Complementarity Approach', Socio-Economic Review, 3 (2005), 311-30; Ekkehard Ernst, 'Financial Systems, Industrial Relations, and Industry Specialization: An Econometric Analysis of Institutional Complementarities', in H. Schubert, ed., The Transformation of the European Financial System (Frankfurt: European Central Bank, 2003), pp. 60-95; Torben Iversen, 'Wage Bargaining, Central Bank Independence and the Real Effects of Money', International Organization, 3 (1998), 469-504; Peter A. Hall and Robert J. Franzese Jr, 'Mixed Signals: Central Bank Independence, Coordinated Wage Bargaining, and European Monetary Union', International Organization, 3 (1998), 505-35; Michel Goyer, 'Capital Mobility, Varieties of Institutional Investors and the Transforming Stability of Corporate Governance in France and Germany', in Hancké, Rhodes and Thatcher, eds, Beyond Varieties of Capitalism, pp. 195-222.

10 This approach originates in the early work of David Soskice and the account given of it here draws extensively on joint work with him. See David Soskice, 'Reinterpreting Corporatism and Explaining Unemployment, Coordinated and Non-coordinated Market Economies', in R. Brunetta and C. Dell'Aringa, eds, Labour Relations and Economic Performance (London: Macmillan, 1990), pp. 170-214; David Soskice, 'The Institutional Infrastructure for International Competitiveness: A Comparative Analysis of the UK and Germany', in A. B. Atkinson and R. Brunetta, eds, The Economics of the New Europe (London: Macmillan, 1991), pp. 45-66. 
THE VARIETIES-OF-CAPITALISM APPROACH

In contrast to the literature focused on national labour movements, varieties-of-capitalism analyses assume that firms are the central actors in the economy whose behaviour aggregates into national economic performance. In order to prosper, firms must engage with other actors in multiple spheres of the political economy: to raise finance (on financial markets), to regulate wages and working conditions (industrial relations), to ensure workers have the requisite skills (education and training), to secure access to inputs and technology (via inter-firm relations), to compete for customers (in product markets), and to secure the co-operation of their workforce (firm-employee relations). Adopting a relational view of the firm, this perspective assumes that success in each of these endeavours depends on efficient co-ordination with other actors. The central problems facing firms are, therefore, co-ordination problems.

The varieties-of-capitalism approach draws a distinction between two modes of co-ordination. In one, firms co-ordinate with other actors primarily through competitive markets, characterized by arms-length relations and formal contracting. Here, equilibrium outcomes are dictated primarily by relative prices, market signals and familiar marginalist considerations. In the second, firms co-ordinate with other actors through processes of strategic interaction of the kind typically modelled by game theory. Here, equilibrium outcomes depend on the institutional support available for the formation of credible commitments, including support for effective information sharing, monitoring, sanctioning and deliberation. ${ }^{11}$

Although instances of market and strategic co-ordination occur in all capitalist economies, this approach contends that, in the spheres central to firm endeavour, the balance between these two types of co-ordination varies across political economies. At one end of the spectrum stand liberal market economies (LMEs), where relations between firms and other actors are co-ordinated primarily by competitive markets. At the other end are co-ordinated market economies (CMEs), where firms typically engage in more strategic interaction with trade unions, suppliers of finance and other actors. ${ }^{12}$

Whether a firm co-ordinates its endeavours through market relations or through strategic interaction is said to depend on the institutional setting. Where markets are imperfect and there is substantial institutional support for the formation of credible commitments, firms can be expected to rely more extensively on strategic co-ordination. Where markets are fluid and there is little support for such commitments, firms will rely more heavily on market co-ordination. Accordingly, there should be a correspondence between the institutional configuration of each sphere of the economy and the character of co-ordination there. ${ }^{13}$

11 This list of the institutional correlates of effective strategic co-ordination is a familiar one that draws on the conventional literature plus the presence of a capacity for deliberation whose importance is outlined in Hall and Soskice, 'Introduction'. See Elinor Ostrom, Governing the Commons: The Evolution of Institutions for Collective Action (New York: Cambridge University Press, 1990).

${ }^{12}$ The approach concentrates on cross-national variation because it examines spheres where national regulations and nationally-specific institutions are especially important, but it acknowledges there can be additional variation across specific regions or sectors. See John L. Campbell, Rogers Hollingsworth and Leon Lindberg, Governance of the American Economy (New York: Cambridge University Press, 1991); and Gary Herrigel, Industrial Constructions: The Sources of German Industrial Power (New York: Cambridge University Press, 1996).

${ }^{13}$ Of course, the distinction between institutions and co-ordination is a narrow one, especially if coordination is construed as rule-patterned behaviour. Here, institutions are defined as rules and practices, more or less formal, that actors take into account when making decisions about what actions to undertake. These include the institutions generated by the organizational setting. See Hall and Soskice, 
The distinction will be clearer if we describe a liberal and co-ordinated market economy. Market co-ordination is a familiar concept in neo-classical economics, and the United States is a typical LME. Here, firms face large equity markets marked by high levels of transparency and dispersed shareholding, where firms' access to external finance depends heavily on publicly assessable criteria such as market valuation. Regulatory regimes allow hostile takeovers that depend on share price, rendering managers sensitive to current profitability. Because trade unions are relatively weak and employment protection low, labour markets are fluid and wage setting primarily a matter of contract between workers and individual employers. Because labour markets are fluid, workers have incentives to invest in general skills that can be taken to other jobs, and, because industry associations are weak, firms lack the capacity to mount the collaborative training programmes that confer industry-specific skills. Technology transfer is accomplished primarily by licensing or taking on expert personnel, and standards are usually set by market races. Top managers enjoy substantial authority over all aspects of firm strategy, including lay-offs. In such settings, many of the relationships firms form with other actors are mediated by competitive markets. Although there are variations between them, the United Kingdom, Ireland, Canada, Australia and New Zealand are all generally identified as LMEs.

Germany provides a good example of a CME. Its firms are closely connected by dense networks of cross-shareholding and influential employers associations. These networks provide for exchanges of private information, allowing firms to develop reputations that permit some access to capital on terms that depend more heavily on reputation than share value. Accordingly, managers are less sensitive to current profitability. In the presence of strong trade unions, powerful works councils and high levels of employment protection, labour markets are less fluid and job tenures longer. In most industries, wage setting is co-ordinated by trade unions and employers associations that also supervise collaborative training schemes, providing workers with industry-specific skills and assurances of positions if they invest in them. Industry associations play a major role in standard setting, and substantial amounts of technology transfer take place through inter-firm collaboration. Hemmed in by powerful workforce representatives and business networks, top managers have less scope for unilateral action, and firms typically adhere to more consensual styles of decision making. It should be apparent that, in order to perform their core functions, firms in CMEs like that of Germany must engage in strategic interaction in multiple spheres, although the institutions on which they rely and the quality of the outcomes may vary from one country to another. Austria, Japan, South Korea, Sweden, Norway, Finland, Denmark, Belgium, the Netherlands and Switzerland are usually identified as CMEs.

\section{ESTABLISHING CO-ORDINATION AS A CRUCIAL DIMENSION}

We begin our analysis by examining the core contention of the varieties-of-capitalism approach that the developed economies differ from one another according to the extent to which firms depend on market or strategic co-ordination to accomplish their endeavours. Of course, the character of co-ordination is difficult to measure directly. However, as Hall

(F'note continued)

'Introduction', p. 9; Randall Calvert, 'The Rational Choice Theory of Social Institutions: Cooperation, Coordination and Communication', in J. Banks and E. Hanushek, eds, Modern Political Economy (New York: Cambridge University Press, 1995), pp. 216-67. 
and Soskice point out, the nature of co-ordination depends on the type of institutions available to support it. Accordingly, a factor analysis designed to identify commonalities that may be unobservable in themselves but that correlate with a range of observable variables provides an appropriate technique for identifying the character of co-ordination. ${ }^{14}$ By performing a factor analysis on a set of institutional measures that are commonly associated with one type of co-ordination or another, we can assess whether the dimensions of market and strategic co-ordination posited by varieties-of-capitalism theory exist and where they are present. Varieties-of-capitalism theory generates three hypotheses that can be tested using such an analysis:

HYPOTHESIS 1: The character of co-ordination constitutes a key dimension stretching across spheres of the political economy.

If this is correct, a confirmatory factor analysis in which the latent variables are defined as the degree of co-ordination in each sphere of the political economy should do a good job in accounting for the observed covariance between a set of indicators representing the institutional conditions associated with different types of co-ordination in those spheres.

HYPOTHESIS 2: The underlying latent variables corresponding to each sphere of the economy should reflect variation along a spectrum running from market co-ordination to strategic co-ordination.

If this is correct, the factor loadings produced by the confirmatory factor analysis should be consistent. This means that if an observable indicator of institutional support for strategic co-ordination loads positively (negatively) onto a given latent variable, other indicators of support for strategic co-ordination should also have positive (negative) factor loadings for this latent variable. Conversely, indicators of support for market co-ordination should have negative (positive) factor loadings.

HYPOTHESIS 3: It is possible to identify a distinctive set of LMEs that make extensive use of market co-ordination and another set of CMEs that make extensive use of strategic co-ordination.

If this is correct, when the factor loadings are used to construct scores for each nation, the nations identified by the case study literature as LMEs should be located towards the 'market' end of the dimension for each sphere, and those identified as CMEs should be located closer to the 'strategic' end for each sphere.

The central obstacle to such an analysis is the paucity of relevant indicators available for more than a few countries. The measurement of co-ordination poses special difficulties. In principle, types of co-ordination are observable, but intense observation is required. In only one sphere has co-ordination been assessed in this way, namely that of wage bargaining. Accordingly, we employ two independent assessments of co-ordination in wage bargaining. The other variables used in the factor analysis are all indicators of institutional features of the political economy that can reasonably be said to reflect or provide support for one type of co-ordination or the other. We have identified variables that extend across two important spheres of the political economy, those pertinent to labour relations and corporate governance. The observations were drawn from the 1990-95 period, the latest for which comparable data is available.

${ }^{14}$ Kenneth A. Bollen, Structural Equations with Latent Variables (New York: Wiley, 1989). 
The variables employed in the factor analysis are as follows: ${ }^{15}$

Shareholder power: reflects the legal protection and likely-influence over firms of ordinary shareholders relative to managers or dominant shareholders. It is a composite measure of legal regulations covering six issues: the availability of proxy voting, deposit requirements for shares, the election of directors, the legal recourse available to minority shareholders, shareholders' rights to issues of new stock and the calling of shareholder meetings. Regulations governing each issue are coded 0 or 1 and summed. Higher scores indicate that ordinary shareholders enjoy more rights vis-à-vis managers and dominant shareholders. ${ }^{16}$

Dispersion of control: indicates how many firms in the economy are widely held relative to the number with controlling shareholders. Taking the smallest ten firms with market capitalization of common equity of at least $\$ 500$ million at the end of 1995 as a sample of firms, it reports the percentage that do not have a controlling shareholder, defined as one who controls, directly or indirectly, more than 10 per cent of the voting rights in the firm. Higher values indicate that larger proportions of firms in the economy are widely held. ${ }^{17}$ Size of stock market: the market valuation of equities on the stock exchanges of a nation as a percentage of its gross domestic product in $1993 .^{18}$

Level of wage co-ordination: the level at which unions normally co-ordinate wage-claims and employers co-ordinate wage-offers where 3 represents the national level, 2 the intermediate level, and 1 firm level. Levels of co-ordination for unions and employers are assessed separately and averaged. Higher values indicate higher levels of co-ordination in wage setting. 19

Degree of wage co-ordination: reflects estimates by the OECD Secretariat of the degree to which wage bargaining is (strategically) co-ordinated by unions and employers along a scale on which 3 indicates co-ordinated and 1 indicates uncoordinated. Observations are for 1994. Higher values indicate higher levels of wage co-ordination. ${ }^{20}$

Labour turnover: is an indicator of the fluidity of national labour markets and reports the number of employees who had held their jobs for less than one year as a percentage of all employees surveyed in $1995 .^{21}$

The appropriateness of these variables for the analysis should be apparent from our description of LMEs and CMEs. The first three variables reflect institutional variation in the sphere of corporate governance of the sort highlighted by the varieties-of-capitalism approach. Where the balance of influence tilts towards dominant shareholders, ownership is relatively concentrated and equity markets are small, securing access to external finance and negotiating corporate control is more likely to involve firms in strategic interaction within corporate networks. When these conditions are reversed, issues of finance and

\footnotetext{
15 Further details of the derivation and definition of these measures can be found in the original sources.

16 LaPorta, Lopez-de-Silanes, Schleifer and Vishny, 'Law and Finance', p. 1130.

17 Rafael LaPorta, Florencio Lopez-de-Silanes and Andrei Schleifer, 'Corporate Ownership Around the World', Journal of Finance, 54 (1999), 471-517, Table II, Panel B.

18 See OECD website at www.oecd.org/topic/corporate.

19 Richard Layard, Stephen Nickell and Richard Jackman, Unemployment: Macroeconomic Performance and the Labour Market (Oxford: Oxford University Press, 1991), p. 52.

${ }^{20}$ Organization for Economic Cooperation and Development, Employment Outlook (June 1997), p. 71.

21 Organization for Economic Cooperation and Development, Employment Outlook (June 1997), p. 138. The value for New Zealand on this variable is estimated using a multiple imputation technique.
} 


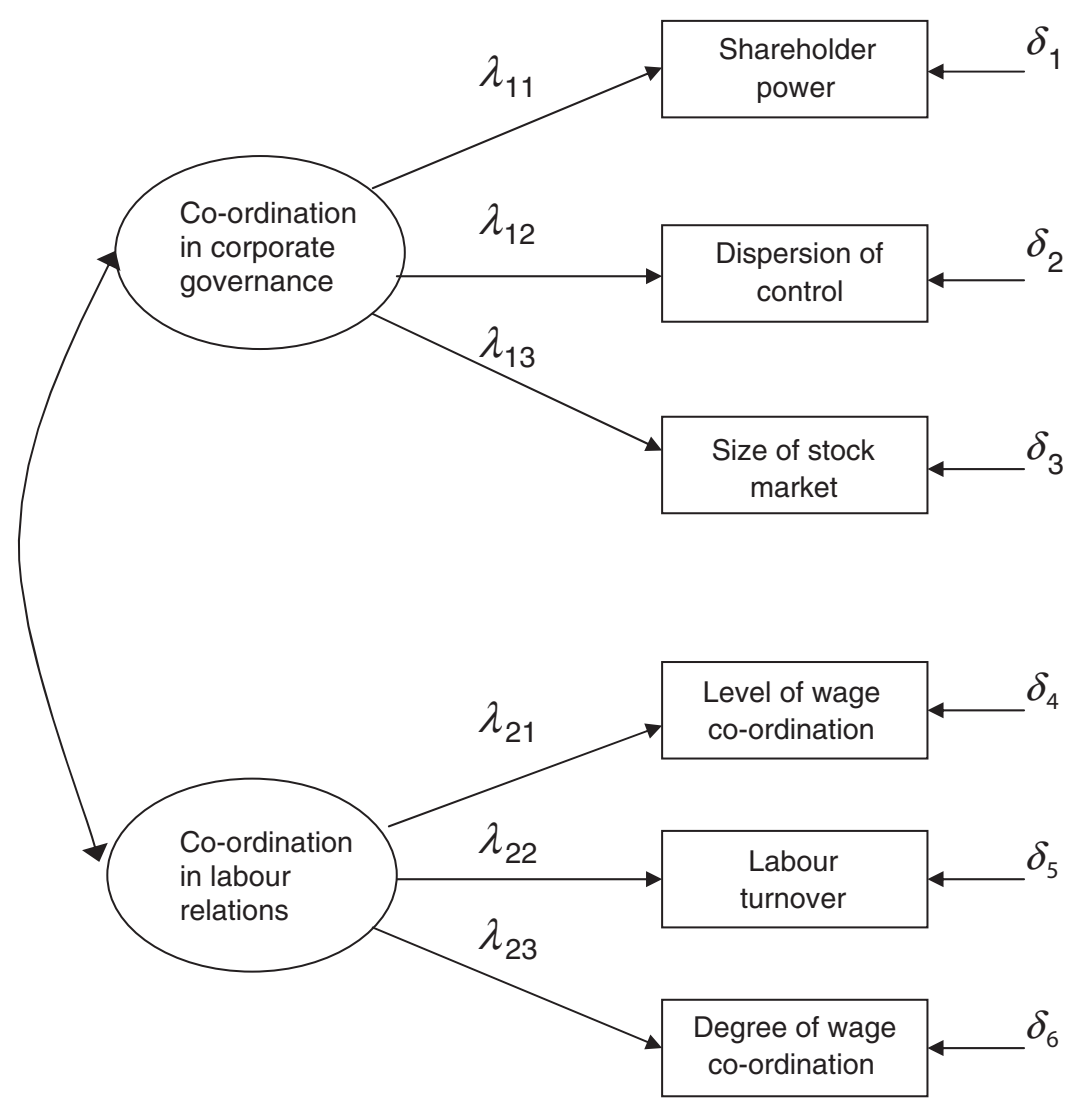

Fig. 1. Path diagram of the two-factor model for the six observed variables

corporate control are determined by more competitive markets. The next three variables reflect relevant variation in the sphere of labour relations. Two assess the level and degree of strategic co-ordination in wage bargaining. Labour turnover reflects the frequency with which workers move between firms, a measure of the fluidity of labour markets.

Since the number of indicators available for such an analysis is limited and the likelihood of some measurement error high, we entered the analysis with low expectations. Given these constraints, the results are highly supportive of the terms the varieties-of-capitalism literature uses to characterize political economies. We performed the confirmatory factor analysis whose structure is presented in Figure $1 .^{22}$ Table 1 reports the estimates of the linear

22 The path diagram reflects the following assumptions. First, we assume that the covariance among our observed variables is a function of the presence of two latent (unobservable) variables: the balance between market-based and strategic co-ordination in the sphere of corporate governance and in the sphere of labour relations. Secondly, we assume that each latent variable is linearly related to the corresponding observable variables within its particular sphere of the economy. Co-ordination in one sphere of the economy does not exert a direct linear effect on the level of the observable variables found in the other sphere of the economy. Thirdly, we assume that our two latent variables are correlated: given the presence of institutional complementarities, we would expect countries characterized by high levels of one type of co-ordination in one sphere to have high levels of co-ordination in the other sphere. Thus, the empirical 
TABLE 1 Parameter Estimates of Co-ordination in Corporate Governance and Labour Relations (Confirmatory Factor Analysis)

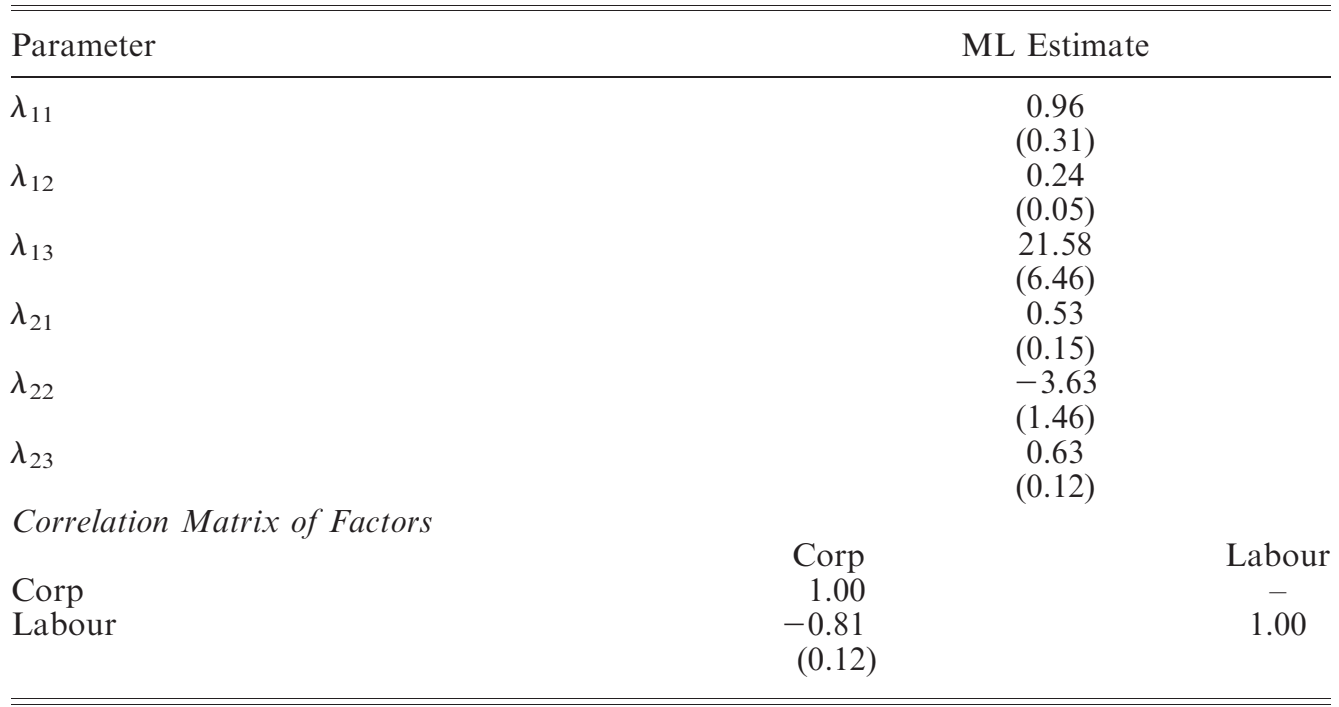

Notes: $N=20$. Standard errors are shown in parentheses. $\chi^{2}=4.71(p$ value $=0.79)$ Normalized Fit Index $(\mathrm{NFI})=0.95$. Goodness of Fit Index $(\mathrm{GFI})=0.92$. Adjusted Goodness of Fit Index $(\mathrm{AGFI})=0.80$.

relationship between the latent and observable variables (factor loadings) as well as a set of indicators of the 'goodness of fit' of the overall model. All of the factor loadings were significant by conventional standards and signed in the appropriate manner. The fit indicators suggest the model does a good job of explaining the covariance among the observed variables. As expected, the estimated correlation between the levels of co-ordination found in each sphere of the economy was high $(-0.81) .{ }^{23}$ These results suggest that the first two hypotheses examined here should be accepted rather than rejected.

How well do these results conform to the cross-national patterns postulated by the varieties-of-capitalism literature? Using the factor loadings, we construct scores for each nation for each factor, normalized to lie between 0 and 1 . These scores are reported in Table 2, and Figure 2 arrays each of the Organization for Economic Cooperation and Development (OECD) nations for which we have scores in a two dimensional space where movement away from the origin along the $\mathrm{X}$-axis reflects higher levels of strategic (versus market) co-ordination in corporate governance and movement up the Y-axis reflects

\footnotetext{
(F'note continued)

model reflects our theoretical belief that variation in the observable variables found in one sphere of the economy is related to the level of co-ordination found in the other sphere of the economy only by way of the correlation between the levels of co-ordination in the two spheres, which in turn is a function of the presence of institutional complementarities. Our final assumption is that measurement error across our observable variables is uncorrelated.

${ }^{23}$ The estimated correlation is negative because the latent factor driving the covariance between the corporate governance indicators is the degree of strategic co-ordination whereas the latent factor driving the covariance between the labour relations indicators is the degree of market co-ordination (i.e. strategic co-ordination in reverse).
} 
TABLE 2 Co-ordination in Labour Relations and Corporate Governance

\begin{tabular}{lcc}
\hline \hline & Labour relations & Corporate governance \\
\hline Australia & 0.29 & 0.47 \\
Austria & 1.00 & 1.00 \\
Belgium & 0.50 & 0.77 \\
Canada & 0.09 & 0.23 \\
Denmark & 0.58 & 0.65 \\
Finland & 0.66 & 0.71 \\
France & 0.60 & 0.82 \\
Germany & 0.92 & 0.95 \\
Ireland & 0.28 & 0.35 \\
Italy & 0.77 & 0.99 \\
Japan & 0.94 & 0.72 \\
Netherlands & 0.53 & 0.74 \\
New Zealand & 0.09 & 0.27 \\
Norway & 0.81 & 0.74 \\
Portugal & 0.62 & 0.85 \\
Spain & 0.54 & 0.77 \\
Sweden & 0.59 & 0.71 \\
Switzerland & 0.48 & 0.44 \\
United Kingdom & 0.04 & 0.14 \\
United States & 0 & 0 \\
\hline
\end{tabular}

Note: Factor scores were constructed using Thomson's regression method with correlated factors and then normalized to be between 0 and 1 (see Derrick N. Lawley and Albert E. Maxwell, Factor Analysis as a Statistical Method (London: Butterworths, 1963)).

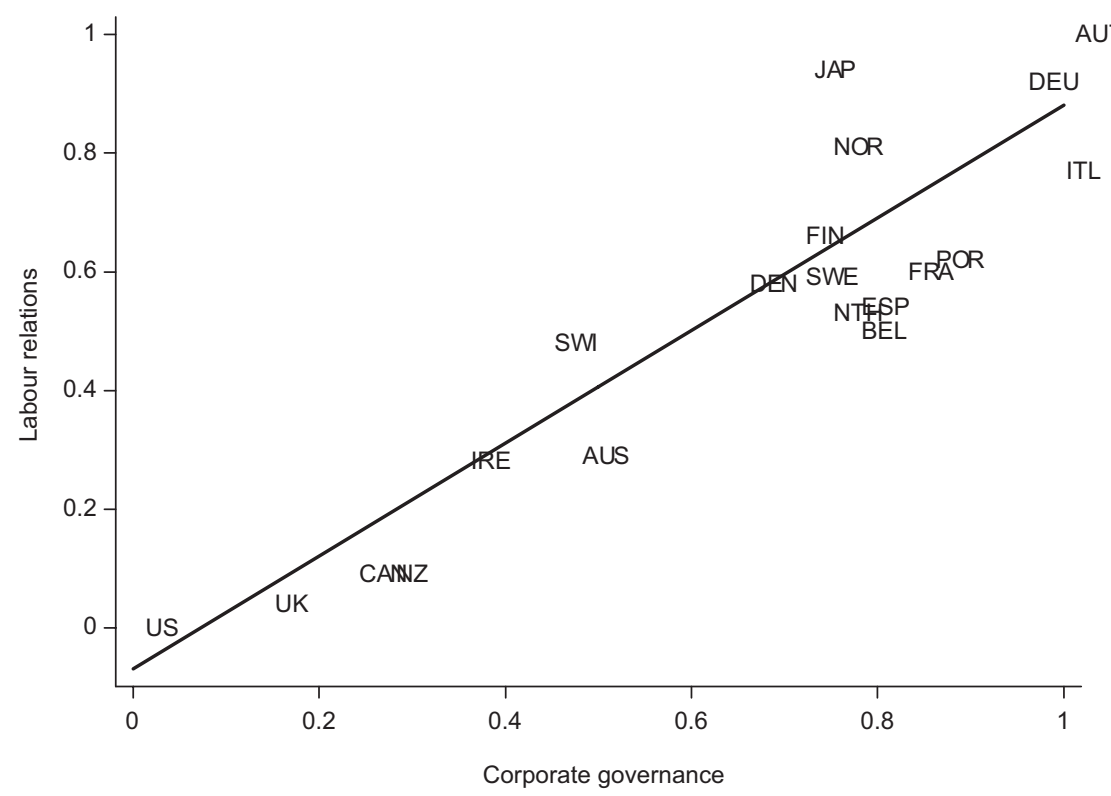

Fig. 2. The balance between market and strategic co-ordination in labour relations and corporate governance in $O E C D$ countries

Note: On each axis, movement away from the origin indicates higher levels of strategic co-ordination in the relevant sphere of the political economy and movement towards the origin indicates higher levels of market co-ordination. 
higher levels of strategic co-ordination in labour relations. If the varieties-of-capitalism approach to understanding the institutional differences among developed political economies is correct, we should expect to see a clustering pattern: LMEs and CMEs should be found primarily in the southwest and northeast quadrants, respectively.

The results are broadly supportive of the hypothesis. As the regression line indicates, there is a strong and statistically significant relationship in the predicted direction between co-ordination in labour relations and corporate governance. Nations cluster towards the southwest and northeast quadrants of the diagram, as the theory would lead us to expect. Six nations, all normally identified by varieties-of-capitalism theory as LMEs, cluster to the southwest, on or below the regression line. The economies of northern Europe, generally identified as CMEs, cluster towards the northeast in this two-dimensional space.

Switzerland is the most obvious outlier. We view its position as the result of measurement error associated with the limitations of our measure for co-ordination in corporate governance. Our measure attaches considerable weight to the size of the stock market and Switzerland has a large stock market relative to its gross domestic product. But there is also extensive cross-shareholding in this nation not picked up by our measure of shareholder dispersion because many of the relevant holdings fall below our 10 per cent cutoff point. ${ }^{24}$ Nevertheless, these cross-shareholdings limit hostile takeovers and serve as vehicles for network monitoring. In short, we think an accurate assignment of this case would put it into the northeast quadrant of the diagram. The co-ordination of labour relations in the Netherlands and Belgium may also be underestimated here, reflecting OECD figures that may underestimate co-ordination in labour relations. Given the potential for such measurement error in indices taken entirely from external sources, however, the correspondence between the location of economies in Figure 2 and the account of such economies given by the varieties-of-capitalism literature is striking.

The proximity of various nations to one another in this institutional space also facilitates more fine-grained assessment of variations among the OECD economies. Correcting for measurement error, there are four distinct clusters of nations. Among the LMEs, the United States and the United Kingdom appear as relatively 'pure' cases, while four other LMEs stand slightly apart by virtue of systems of corporate governance in which market co-ordination is not as fully developed. On the other side of Figure 2, the nations most often identified as CMEs lie near or above the regression line, indicating high levels of strategic co-ordination in both their labour and financial markets.

Six nations lie to the east in the figure but clearly below the regression line (Sweden lies just slightly below). This is especially interesting because there has been some controversy about whether four of these nations (Spain, Portugal, France and Italy) are CMEs or examples of another distinctive type of capitalism often associated with high levels of state intervention. ${ }^{25}$ Figure 2 clarifies some of the issues that render these ambiguous cases. These nations all have institutional capacities for strategic co-ordination in labour relations and corporate governance that are higher than those of LMEs. However, their

24 Paul Windolf, Corporate Networks in Europe and the United States (New York: Oxford University Press, 2002); Mark J. Roe, 'Political Preconditions to Separating Ownership from Corporate Control', Stanford Law Review, 53 (2000), 539-605.

${ }_{25}$ Schmidt, The Futures of European Capitalism; Amable, The Diversity of Modern Capitalism; Hall and Soskice, Varieties of Capitalism, Martin Rhodes 'Globalisation, Labour Markets and Welfare States: A Future of “Competitive Corporatism'?', in Martin Rhodes and Yves Meny, eds, The Future of European Welfare (London: Macmillan, 1997), pp. 178-203. 
capacities for strategic co-ordination in labour relations tend to be lower than those in northern Europe, probably because their union movements are still divided along what used to be called 'confessional' lines. Although strategic co-ordination is clearly more important in these nations than in LMEs, these findings suggest there may be systematic differences in the operation of southern, as compared to northern, European economies. ${ }^{26}$

\section{CONGRUENCE ACROSS SPHERES OF THE POLITICAL ECONOMY}

Although we have focused on corporate governance and labour relations because they are the two most important spheres of the economy, regulating the supply of labour and capital, the varieties-of-capitalism approach also expects systematic variation, between LMEs and CMEs across other spheres of the political economy, including those concerned with product-market competition, social protection, vocational training and inter-firm relations. Much of the force of the varieties-of-capitalism approach as a theory of comparative capitalism rests on its claim to be able to specify systematic variations across nations that extend to many spheres of the political economy. We turn now to assessment of that claim.

In some cases, the relevant variation is in institutionalized practices; in others, it is in the formal institutions or regulatory regimes that govern endeavours in each sphere. In the varieties-of-capitalism literature, the theoretical basis for expectations of institutional congruence lies in the contention that, where institutional complementarities are available across spheres, firms and governments will often (although not always) adapt their strategies to take advantage of these complementarities. ${ }^{27}$ The relationships on which we focus are as follows.

Varieties-of-capitalism analysts argue that, where labour relations are based on high levels of job mobility and firm-level wage-setting, training systems that provide general skills through formal education will be more efficient than collaborative training schemes that confer industry-specific skills, because workers who must frequently shift jobs have strong incentives to acquire the general skills that qualify them for other positions. Conversely, where labour relations are based on strong unions and co-ordinated wage bargaining, it will be efficient for firms to operate collaborative training schemes conferring high levels of industry-specific skills. High wages set at the industry level encourage workers to acquire industry-specific skills, and they make it more difficult for non-training firms to poach workers by offering wage premiums. The organizations that co-ordinate wages can also be used to co-ordinate training systems. ${ }^{28}$

A similar set of arguments specifies the potential for institutional complementarities between the character of corporate governance and the character of inter-firm relations. Firms are said to find it easier to enter into collaborative arrangements with other firms for the purposes of research, product development or technology transfer - where the

\footnotetext{
26 The varieties-of-capitalism literature acknowledges that such differences may exist. Those between the 'industry-coordinated' economies of northern Europe and 'group-coordinated' economies of Asia have been elaborated most fully. See David Soskice, 'National Patterns in Company Innovation Strategies: A Comparative Institutional Approach' (unpublished paper, Wissenschaftszentrum, Berlin, 1996).

27 Note that our concern here is simply to assess whether the institutional patterns that the varieties-ofcapitalism approach expects to find across nations actually occur and not to assess explanations for why these institutional patterns arise. Many causal processes may underlie such patterns and our analysis is not meant to imply that they arise for any specific set of functional reasons.

${ }^{28}$ David Finegold and David Soskice, 'The Failure of Training in Britain: Analysis and Prescription', Oxford Review of Economic Policy, 4 (1988), 21-53; Pepper Culpepper, Creating Cooperation: How States Develop Human Capital in Europe (Ithaca, N.Y.: Cornell University Press, 2003).
} 
institutions of corporate governance limit the demands on them to maximize current profitability or shareholder value, because they can then make more credible commitments to the incomplete contracts and co-specific investments that such collaboration requires. Conversely, where fluid capital markets facilitate the movement of funds from one endeavour to another, it will be more efficient for firms to access technology by acquiring other enterprises or new personnel rather than engage in long-term collaboration with other firms. ${ }^{29}$

Estevez et al. argue that social policies providing generous employment and unemployment protection will be complementary to production strategies based on the use of specific skills because they provide workers with incentives for acquiring those skills. ${ }^{30}$ Hall and Soskice argue that high levels of product-market regulation may be complementary to financial systems based on network monitoring, to wage co-ordination, and to inter-firm collaboration in research and development because they limit the intensity of competition in product markets that might otherwise undermine co-operation in these other spheres. ${ }^{31}$

The varieties-of-capitalism perspective also identifies potential complementarities between institutional arrangements in the broader political economy and the strategy or structure of firms themselves. This is the basis for an important set of claims that corporate structures and strategies are likely to vary systematically across nations. The theory suggests that, where fluid labour markets facilitate lay-offs and dispersed financial markets often demand them, it will be advantageous for firms to adopt hierarchies that vest management with extensive prerogatives over such matters. Conversely, where strong trade unions or regulatory regimes inhibit lay-offs, corporate structures that provide stakeholders with more influence over enterprise decision making may offer efficiencies by strengthening the credibility of the commitments a firm can make to its employees and thus the levels of co-operation it can secure from them. On such reasoning, the approach contends that firm strategy will vary systematically across political economies in tandem with the institutional support provided there for different types of co-ordination. Firms are said to exploit this institutional support to derive competitive advantages that cumulate into comparative institutional advantages at the national level. ${ }^{32}$

In short, the varieties-of-capitalism literature contends that systematic variation across nations is present not only in labour relations and corporate governance, but also across many other spheres of the political economy, extending to relevant regulatory regimes and firm practices. To assess this contention, we have sought indicators for the types of variation in institutions or practices that varieties-of-capitalism theory expects to find in a

29 Steven Casper, 'High Technology Governance and Institutional Adpativeness' (Discussion Paper 99307, Wissenschaftszentrum, Berlin, 1999); Peter A. Hall and David Soskice, 'An Introduction to Varieties of Capitalism', in Hall and Soskice, eds, Varieties of Capitalism: The Institutional Foundations of Comparative Advantage (Oxford: Oxford University Press, 2001), pp. 1-70.

30 Margarita Estevez-Abe, Torben Iversen and David Soskice, 'Social Protection and Skill Formation: A Reinterpretation of the Welfare State', in Hall and Soskice, eds, Varieties of Capitalism, pp. 145-83; cf. Isabela Mares, 'Firms and the Welfare State: When and How does Social Policy Matter to Employers?', in Hall and Soskice, Varieties of Capitalism, pp. 184-212.

31 See also David Soskice, 'Divergent Production Regimes, Coordinated and Uncoordinated Market Economies in the 1990s', in Herbert Kitschelt, Peter Lange, Gary Marks and John D. Stephens, eds, Continuity and Change in Contemporary Capitalism (New York: Cambridge University Press, 1999), pp. 101-34.

${ }^{32}$ Hall and Soskice, 'Introduction'; and Mark Lehrer, 'From Macro-Varieties of Capitalism to MicroVarieties of Firm Strategy: Applying Comparative Institutional Analysis to Strategic Management', in Hall and Soskice, eds, Varieties of Capitalism, pp. 361-86. 
wide range of spheres of the political economy. Finding indicators for the relevant institutional dimensions is a major challenge if more than a handful of cases are to be considered and we are not to code them ourselves - a technique we have resisted in order to avoid biasing the tests. However, we have found indicators for the relevant types of institutional variation across seven spheres where the varieties-of-capitalism approach suggests major complementarities are available and some institutional congruence should be found. ${ }^{33}$ For labour relations and corporate governance, we use the same indicators employed in the preceding analysis. The others are as follows:

Social protection: refers to the level of support provided to the unemployed and to limitations on the right of firms to lay off workers. We measure it by combining the indices of 'unemployment protection' and 'employment protection' devised by Estevez et al. using the factor scores produced when an exploratory factor analysis is applied to the two indices. Higher values indicate higher levels of social protection. ${ }^{34}$

Product market regulation: refers to the limits placed on competition in product markets by the regulatory restrictions that national governments impose on businesses. The measure is based on an OECD survey of many types of regulatory practices combined into a composite measure through multi-level factor analysis by Nicoletti et al. ${ }^{35}$ Higher values indicate product market regulations more restrictive of competition.

Training systems: are assessed with a view to establishing the extent of institutional support a nation provides for the development of vocational skills in young workers beyond what they secure in formal secondary or university education. In general, this entails apprenticeship schemes or training programmes dependent on the collaborative involvement of firms. The measure is based on the factor scores produced by an exploratory factor analysis on two variables: the number of pupils at the upper secondary level in vocational or technical training programmes as a proportion of all students enrolled in educational programmes and the mean scores on a literacy test secured by a sample of workers between the ages of 20 and 25 who left school before completing secondary education. ${ }^{36}$ Higher values indicate higher levels of institutional support for this kind of vocational training.

Inter-firm relations: refer to the institutionalized practices that link firms to other firms producing goods and services. Of particular relevance is the extent to which firms collaborate with others to secure access to new technology or markets relative to their reliance on competitive market relations for such purposes. Mergers and acquisitions are typical of the latter. Accordingly, the measure is based on the annual number of mergers and acquisitions in a nation in the years 1990-97 expressed as a ratio of its population. ${ }^{37}$ We reverse the direction of the measure so that higher values indicate more inter-firm collaboration.

\footnotetext{
${ }^{33}$ Note that the sample sizes vary for some of these measures.

${ }^{34}$ Estevez-Abe et al. 'Social Protection and Skill Formation'.

${ }^{35}$ Giuseppe Nicoletti, Stefano Scarpetta and Olivier Boylaud, 'Summary Indicators of Product Market Regulation with an Extension to Employment Protection Legislation' (OECD, Economics Department Working Papers No. 226), p. 80.

${ }^{36}$ OECD on-line education database (http://wwwl.oecd.org/scripts/cde/members/linkpage.html); OECD, Literacy in the Information Age (Paris: OECD, 2000), p. 159.

${ }^{37}$ Marco Pagano and Paolo Volpin, 'The Political Economy of Corporate Governance' (Centro Stude in Economia e Finanza, Departimento di Scienze Economiche, Universitya degli Studi di Salerno, Working Paper No. 29, 2000), Table 4.
} 
To assess the ancillary claim that systematic variation in the institutions of the political economy will be associated with distinctive types of firm structures and strategies, we have also sought measures for the latter, as follows:

Managerial prerogative: refers to the extent to which firms concentrate control over their operations in the hands of top management. On the premise that compensation will correspond to the level of responsibility they are assigned for the firm's operations, our measure is the average compensation of chief executive officers as a ratio of the compensation of average production workers in manufacturing in $1999 .{ }^{38}$ Higher values indicate higher levels of managerial prerogative.

Employment tenure: is a measure of the length of time employees typically stay with the same firm, assessed here by median employer tenure in $1995 .{ }^{39}$ This can be read as a reflection of the extent to which firms' strategies turn on the development of close relations with a stable workforce rather than on production regimes that can be operated by more transient and potentially less-skilled labour.

Firm strategy: is a composite measure tapping many of the core practices of firms, including the use they make of multidivisional project teams, participatory work teams, alliances with other firms, close, voice-based relations with suppliers, long-term relations with investors and co-operative labour-management relations built on employment guarantees. Each practice has been coded on a 3-point scale and combined via factor analysis by Hicks and Kenworthy. ${ }^{40}$ Higher values indicate firm strategies that make more extensive use of these 'co-operative' practices.

Using these variables, we test the following hypothesis:

HYPOTHESIS 4: Institutionalized practices extending across the spheres of the political economy identified here, including those associated with firm strategies, vary systematically such that the practices associated with market coordination are present in multiple spheres of political economies classified as LMEs and practices associated with strategic co-ordination are present in multiple spheres of political economies classified as CMEs.

If this is correct, there should be significant correlations across spheres at the national level among the variables representing the institutional practices the varieties-of-capitalism perspective identifies as important to co-ordination.

Figure 3 summarizes the results of this test. The boxes around 'firm strategy' represent the four spheres in which a firm co-ordinates with other actors to accomplish its principal endeavours. The two boxes at the top indicate policy regimes relevant to this co-ordination. The lines between the boxes correspond to hypotheses about complementarities generated by the varieties-of-capitalism literature. Using cross-national comparisons of all the cases for which we have relevant measures, we have calculated correlation coefficients indicating whether the presence of institutional practices of a particular type in one sphere are associated

\footnotetext{
38 Economic Policy Institute, The State of Working America 2000-01 (Washington, D.C.: Economic Policy Institute, 2000).

39 OECD, Employment Outlook (June 1997), p. 138.

40 This measure uses the average 1960-89 scores for a factor that Hicks and Kenworthy label 'firm-level co-operation', which includes some further variables assigned low weights that we do not enumerate here; Alexander Hicks and Lane Kenworthy, 'Cooperation and Political Economic Performance in Affluent Democratic Capitalism', American Journal of Sociology, 103 (1998), 1631-72, p. 1649.
} 


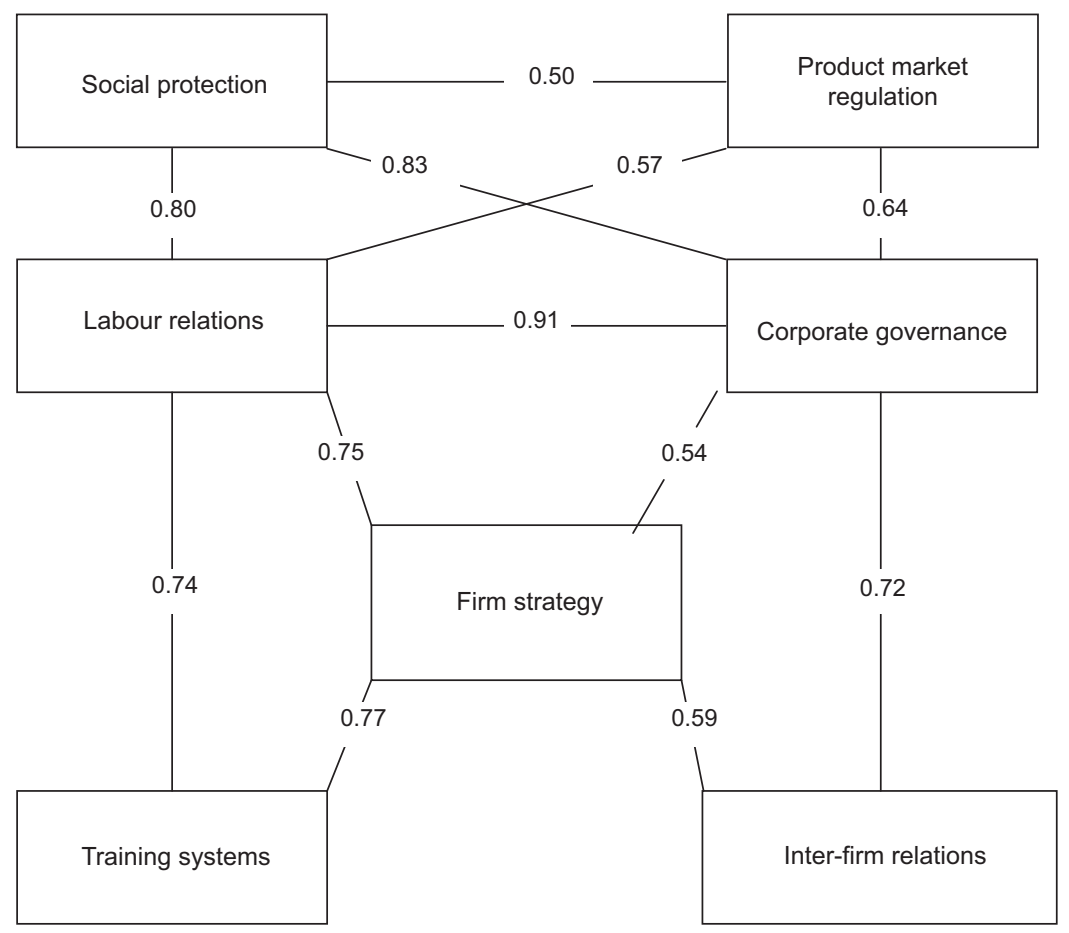

Fig. 3. Potential complementarities across subspheres of the political economy

TA B LE 3 The Relationship Between Institutional Support for Strategic Co-ordination and Corporate strategy

\begin{tabular}{lcc}
\hline \hline & $\begin{array}{c}\text { Correlation with co-ordination in } \\
\text { labour relations }\end{array}$ & $\begin{array}{c}\text { Correlation with co-ordination } \\
\text { in corporate governance }\end{array}$ \\
\hline Employment tenure & 0.686 & 0.660 \\
Managerial prerogative & $(0.002)$ & $(0.003)$ \\
& -0.764 & -0.664 \\
& $(0.002)$ & $(0.013)$ \\
\hline
\end{tabular}

Note: Significance levels in parentheses.

with institutional practices in adjacent spheres that correspond to those posited by a varietiesof-capitalism perspective. That perspective predicts positive coefficients across the diagram. The results are impressive. The coefficients in Figure 3 are uniformly positive and relatively large. All are statistically significant at the 0.05 level. The uniformity of the results is striking. They tend to confirm the varieties-of-capitalism contention that differences based on marketoriented or strategic co-ordination stretch systematically across multiple spheres of the political economy. The results on firm strategy indicated in Figure 3 are also notable: they confirm that corporate strategies tend to vary systematically with the institutional support available for different types of co-ordination in the political economy. Table 3 provides further evidence by comparing the relationship between two indicators for corporate 
strategy and national scores on the co-ordination indices. In each case, there is a strong and statistically significant correlation in the direction posited by the theory.

\section{THE EFFECT OF INSTITUTIONAL COMPLEMENTARITIES ON ECONOMIC GROWTH}

These results indicate that the patterns of institutionalized practices the varieties-of-capitalism perspective expects to see across the developed economies are often present there. We turn now to one of the most important propositions linked to this observation, namely to the claim that there is not only congruence among institutional practices in different spheres of the economy, but that some of these practices can be complementary to others. Institutional practices are said to be complementary when each raises the returns available from the other. We focus on one of the most fundamental sets of complementarities, namely those between institutional practices in the sphere of corporate governance and in labour relations.

Working from the formulations of Aoki, Hall and Soskice develop a theoretical rationale for why such complementarities might exist. ${ }^{41}$ They argue that institutions in the sphere of corporate governance that encourage cross-shareholding and concentrate control in the hands of management, thereby limiting hostile takeovers and providing firms with access to sources of finance that turn on reputational monitoring, enhance the efficiency of institutional practices in the sphere of labour relations that provide high levels of employment security and long job-tenures as well as forms of wage-setting that depend on strategic interaction between employers associations and trade unions. ${ }^{42}$ In the face of a fluctuating economy, firms that do not have to sustain current profitability are better placed to make long-term commitments to their employees about wages and jobs, and therefore to realize the gains available from deploying production regimes based on such commitments. This combination of institutions corresponds to the institutional patterns in CMEs.

Conversely, where firms are more dependent on dispersed equity markets, face the prospect of hostile takeovers, and confront regulations that give shareholders more power relative to stakeholders, the autonomy of the firm and its managers will be more dependent on current profitability. Here, labour markets allowing for high levels of labour turnover and competitive wage-setting will be more efficient, because they enable managers to reduce staffing levels quickly or to hold down wages in response to fluctuations in current profitability. This combination of institutional practices corresponds to the case of a LME. In summary terms, the efficiencies available to firms should be higher in settings where the spheres of labour relations and corporate governance are both dominated by the practices characteristic of either strategic or market co-ordination and, according to the varieties-of-capitalism analysis, these efficiencies should show up in improved aggregate economic performance. ${ }^{43}$

\footnotetext{
41 Masahiko Aoki, 'Toward an Economic Model of the Japanese Firm', Journal of Economic Literature, 28 (1990), 1-27; Aoki, 'The Japanese Firm as a System of Attributes'; Hall and Soskice, 'Introduction'.

${ }^{42}$ When we say that one institutional practice enhances the efficiency of another, this means that its presence increases the returns available from using the other institutional practice.

43 The terms 'market' and 'strategic' co-ordination refer to broad patterns of firm behaviour that tend to be altered only by large-scale institutional changes: no one has suggested that any measure to introduce some competition into one of these spheres necessarily impairs strategic co-ordination in the other. Similarly, although these institutions also have distributive effects that increase the returns to particular actors, following the varieties of capitalism literature, we focus here on returns to the economy as a whole of the sort reflected in aggregate economic performance.
} 
Our indicator for aggregate economic performance will be rates of economic growth per capita, widely accepted as the best measure of such performance and appropriate for testing postulates about the general efficiency of the economy. Moreover, this measure provides an exceptionally hard test for institutional analyses such as these. Because aggregate rates of growth depend on the efficiency of the entire economy, specific sets of institutions will have to make substantial contributions to efficiency to show up in aggregate rates of growth. To summarize the character of co-ordination in labour relations and corporate governance, we use the two indices developed here. Although timevariant measures would be preferable, the difficulties of measuring co-ordination and data limitations preclude them. However, we think the use of these two indices is appropriate because they capture differences across political economies widely seen as stable over time. As a check on this, we examined Kenworthy's measures for co-ordination in wage setting, which do vary over time. ${ }^{44}$ On his measure, only three of our eighteen countries evince much fluctuation over the 1971-97 period, and we assess the specific import of those cases for our results below. Our own examination of institutional change in the 1980s and 1990s also finds considerable stability in the cross-national differences relevant to co-ordination. Therefore, this approach to the measurement of co-ordination should be adequate for the purposes at hand.

We estimate the interaction effects between these two measures of co-ordination and their impact, with a range of appropriate controls standard in the growth literature, on annual rates of per capita economic growth for twenty OECD nations from 1971 to 1997 , taking two different econometric approaches to the panel data. ${ }^{45}$ The two estimators we employed were pooled ordinary least squares regression with panel-corrected standard errors and the generalized least squares random effects estimator. ${ }^{46}$ The former is traditionally employed for times-series cross-section data, i.e. datasets in which the number of observations over time is large relative to the number of panels. The technique produces correct standard errors in the presence of an error term that is heteroscedastic and contemporaneously correlated across countries. The latter is traditionally employed for panel data, i.e. datasets in which the number of panels is large relative to the observations over time. This technique produces consistent coefficient estimates and standard errors in the presence of a composite error term that consists of a (mean zero) time-invariant, countryspecific disturbance (representing unmeasured features of a polity that remain fixed over time) and a traditional country-year disturbance. Since the number of panels and time periods in our dataset were roughly equivalent $(N=20, T=27)$, we present the results for both estimators. $^{47}$

For each econometric technique, we estimate two separate regression equations, one containing the co-ordination indices and their interaction effect along with a standard set of economic controls, and another containing the co-ordination indices and their interaction effect, the economic controls and a set of political institutional variables. The two

\footnotetext{
44 Lane Kenworthy, 'Wage Setting Coordination Scores. 2001'. Available at http://www.u.arizona. edu/ 1kenwor/WageCoorScores.pdf

45 The countries included in the estimations consist of all those for which it was possible to calculate the co-ordination indices. See Table 2 for the complete list.

${ }^{46}$ Nathaniel Beck and Jonathan Katz, 'What to Do (And Not to Do) with Time-Series Cross-Section Data', American Political Science Review, 89 (1995), 634-48.

47 One of the more common approaches to statistical analysis with panel data, namely, fixed effects regression, was unavailable to us as a result of the time-invariant nature of our co-ordination indices.
} 
equations estimated were the following:

$$
\begin{aligned}
Y_{i t}= & \beta_{0}+\beta_{1} C_{i}^{L R}+\beta_{2} C_{i}^{C G}+\beta_{3} C_{i}^{L R} \cdot C_{i}^{C G}+\beta_{4} \ln G D P_{i}+\beta_{5} \text { Int }_{i t}+\beta_{6} \pi_{i t}+\beta_{7} \text { Exp }_{i t} \\
& +\beta_{8} D_{i t}+\varepsilon_{i t} \\
Y_{i t}= & \beta_{0}+\beta_{1} C_{i}^{L R}+\beta_{2} C_{i}^{C G}+\beta_{3} C_{i}^{L R} \cdot C_{i}^{C G}+\beta_{4} \ln G D P_{i}+\beta_{5} \text { Int }_{i t}+\beta_{6} \pi_{i t}+\beta_{7} \text { Exp }_{i t} \\
& +\beta_{8} D_{i t}+\beta_{9} P L U_{i t}+\beta_{10} M A G_{i t}+\text { Leftcab }_{i t}+\varepsilon_{i t}
\end{aligned}
$$

where $C_{i}^{L R}$ represents the character of co-ordination in labour relations in country $i$ and $C_{i}^{C G}$ represents the character of co-ordination in its sphere of corporate governance. Estimation of these models was used to test the following hypothesis derived from the varieties-of-capitalism perspective on institutional complementarities:

HYPOTHESIS 5: When there are higher levels of market (strategic) co-ordination in the sphere of labour relations or corporate governance, rates of economic growth increase as the level of market (strategic) co-ordination in the other sphere increases.

If this is correct, the interaction term in the model, $C_{i}^{L R} \cdot C_{i}^{C G}$, should be statistically significant and positive. A significant coefficient indicates that the impact of co-ordination in one sphere is dependent on the character of co-ordination in the other sphere, and a positive coefficient indicates that analogous types of co-ordination in the two spheres raise rates of growth.

The controls employed here are standard for estimating rates of economic growth: $\ln G D P_{i}$ is the log of gross domestic product per capita for country $i$ at the beginning of the time period considered in this article, controlling for 'catch up' effects that generate higher rates of growth in nations at lower levels of economic development. Int ${ }_{i t}$ represents international demand conditions measured by the average rate of growth for all countries in our sample in period $t$ excluding country $i$, weighted by the trade openness of country $i$. The country's rate of inflation measured by the rate of increase in its consumer price index is $\pi_{i t}$. In the developed world, where rates of inflation are moderate, we expect them to be positively related to rates of growth. $\operatorname{Exp}_{i t}$ is the percentage change in the income terms of trade for country $i$ weighted by trade openness: adverse movements should lower rates of economic growth. $D_{i t}$ is the dependency ratio measured as the share of the population below the age of 15 or above the age of 65. A higher proportion of dependents is expected to lower rates of economic growth.

In recent years, political economists have evinced growing concern for the influence of electoral institutions on political rents, productivity and economic growth. ${ }^{48}$ Accordingly, in our second regression equation, we include two variables to capture the potential influence of the electoral-institutional environment: $P L U_{i t}$, is an indicator variable equal to 1 if a majority of representatives in the lower house are elected by plurality voting and 0 otherwise; and $M A G_{i t}$, is the average district magnitude in the lower chamber. Based on the literature on political rents, we expect $P L U_{i t}$ to be associated with higher economic growth and, since low district magnitude is a proxy for barriers to entry in the political system, higher levels of $M A G_{i t}$ may be associated with greater economic growth. In addition, we include a variable designed to capture the influence of partisan preferences: Leftcab $_{i t}$ reflects left party cabinet portfolios as a proportion of total cabinet portfolios. Detailed variable descriptions are provided in Appendix Table A1.

${ }^{48}$ T. Persson and G. Tabellini, The Economic Effects of Constitutions (Cambridge, Mass.: MIT Press, 2003). 


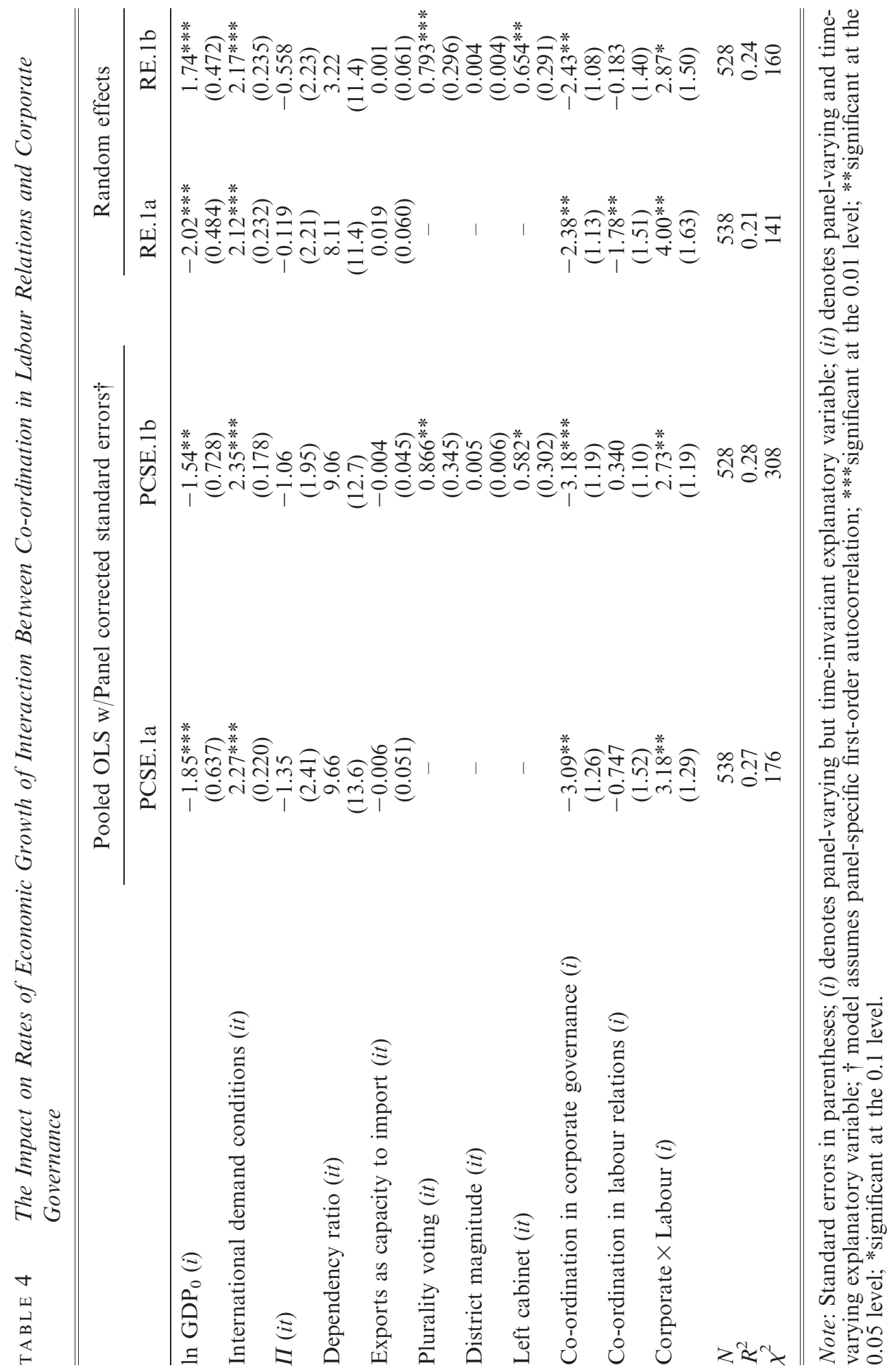


Table 4 reports the results of the estimations. The parameter estimates are broadly stable across the four models. In all the models estimated, the coefficient on the interaction term is positive, of considerable magnitude, and statistically significant. These results tend to confirm the presence of substantial complementarities between the spheres of labour relations and corporate governance of the sort postulated by varieties-of-capitalism theory.

Using model RE.1a for the purposes of simulation, Figure 4 depicts the impact of co-ordination in corporate governance on economic growth for different levels of coordination in labour relations (holding control variables fixed at their mean values). Two trajectories are shown. In the first case, co-ordination in labour relations is held constant at its minimum value $(0)$ and co-ordination in corporate governance is allowed to vary from minimum (0) to maximum (1). In this instance, the predicted growth rate declines from 2.99 per cent to 0.61 per cent. In the second case, co-ordination in labour relations is held constant at its maximum value (1) and co-ordination in corporate governance is allowed to vary from minimum to maximum. In this instance, the predicted growth rate increases from 1.21 per cent to 2.83 per cent.

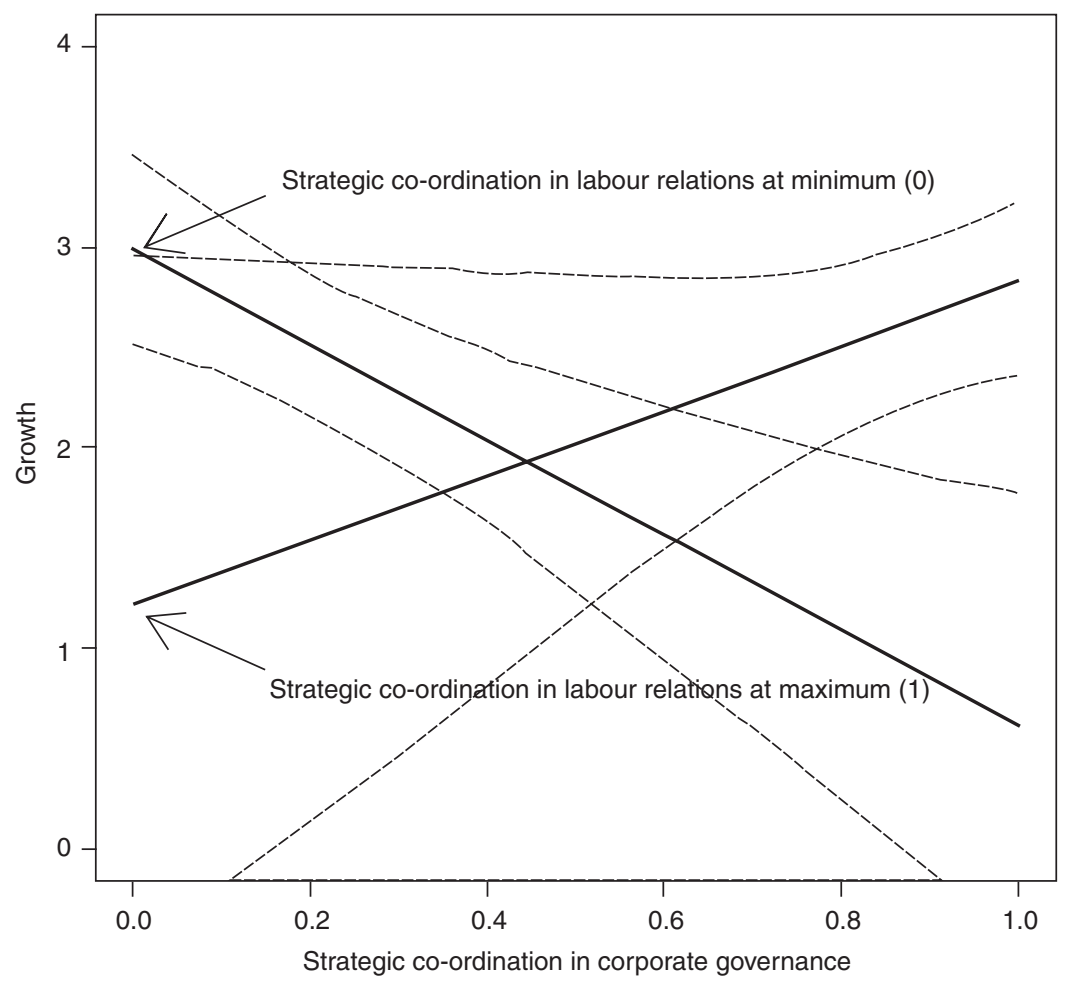

Fig. 4. The effect on rates of economic growth of the interaction between types of co-ordination in labour relations and corporate governance

Note: Movement from the origin along the $\mathrm{X}$-axis indicates that co-ordination in corporate governance becomes more strategic. Predicted values denoted by solid dark lines, 90 per cent confidence intervals denoted by dashed lines; simulation based on model RE.1a.

The simulations show clear evidence of interaction effects between the character of co-ordination in the two spheres. Rates of growth are highest where competitive markets co-ordinate both spheres, or where strategic co-ordination is high in both. Where labour 
relations are strategically co-ordinated, substantial efficiencies seem to be available from strategic co-ordination in the sphere of corporate governance. Where corporate governance is dominated by fluid equity markets, however, rates of growth are substantially higher when labour markets are also fluid and competitive.

Although it is beyond the scope of this article to test for the presence of specific complementarities across other spheres of the political economy, we conduct one other assessment of these contentions at the aggregate level. The varieties-of-capitalism approach implies that aggregate economic performance should be better in nations whose institutionalized practices correspond more closely to relatively pure types of LMEs or CMEs. Long-term rates of growth should be higher in countries where market or strategic co-ordination is more fully developed across multiple spheres of the political economy, compared to those where the type of co-ordination varies across spheres or where either type of co-ordination is secured but in less complete form. This implication yields the following hypothesis:

HYPOTHESIS 6: Rates of economic growth should be higher in nations where levels of market co-ordination or levels of strategic co-ordination are high across spheres of the political economy but lower in nations where neither type of co-ordination is so well-developed, or market and strategic co-ordination are combined.

If this is correct, estimates for rates of growth when other relevant factors are controlled should show higher rates of growth in nations where levels of market or strategic co-ordination are consistently high across spheres and lower rates in other nations.

In order to test this hypothesis, we created a single co-ordination index using the separate indices of co-ordination in corporate governance and labour relations. The co-ordination index measuring the balance of market and strategic co-ordination in the political economy for country $i$ is equal to:

$$
C_{i}=\left(C_{i}^{C G}+C_{i}^{L R}\right) / \max \left(C_{i}^{C G}+C_{i}^{L R}\right),
$$

where $C G_{i}$ and $L R_{i}$ refer to the score of country $i$ on the co-ordination in corporate governance and co-ordination in labour relations indices, respectively. We then estimated the effect of co-ordination on annual rates of per capita economic growth for OECD nations from 1971 to 1997 using regression models of the following form:

$$
\begin{aligned}
Y_{i t}= & \beta_{0}+\beta_{1} C_{i}+\beta_{2} C_{i}^{2}+\beta_{3} \ln G D P_{i}+\beta_{4} \text { Int }_{i t}+\beta_{5} \pi_{i t}+\beta_{6} \operatorname{Exp}_{i t}+\beta_{7} D_{i t}+\varepsilon_{i t} \\
Y_{i t}= & \beta_{0}+\beta_{1} C_{i}+\beta_{2} C_{i}^{2}+\beta_{3} \ln G D P_{i}+\beta_{4} \text { Int }_{i t}+\beta_{5} \pi_{i t}+\beta_{6} \operatorname{Exp}_{i t}+\beta_{7} D_{i t} \\
& +\beta_{8} P_{L} U_{i t}+\beta_{9} M A G_{i t}+\beta_{10} \text { Leftcab }_{i t}+\varepsilon_{i t}
\end{aligned}
$$

If the relationship between growth and co-ordination is U-shaped, $\beta_{1}$ should be negative and $\beta_{2}$ positive. The controls are the standard ones used previously and, once again, we estimated the model using two different types of econometric specifications.

Table 5 reports the results of these four estimations. In all, the coefficients on co-ordination are significant, of the same sign, and of similar magnitude, increasing our confidence in the results. The significance and signs of the coefficients on $C_{i}$ and $C_{i}^{2}$ indicate that the relationship between co-ordination and economic growth is non-linear. Using model RE.2a for the simulation, Figure 5 shows the estimated relationship between 


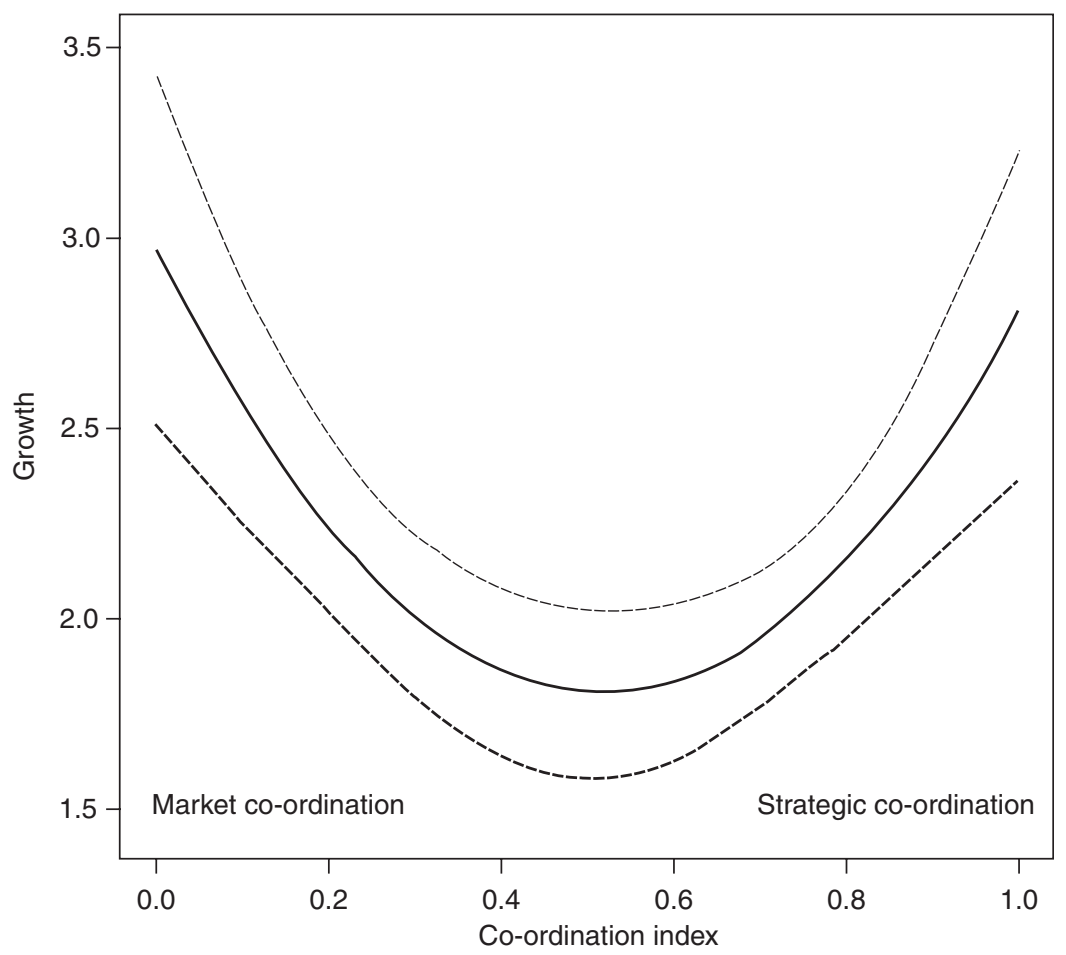

Fig. 5. The estimated relationship between co-ordination and rates of economic growth

Note: Predicted values are denoted by solid dark lines, 90 per cent confidence intervals denoted by dashed lines; simulation based on model RE.2a.

co-ordination and growth when the control variables are held at their means. The U-shaped relationship is apparent. Where the institutional structure of the political economy allows for either higher levels of market co-ordination or higher levels of strategic co-ordination, estimated growth rates are larger than they are when there is more variation in the types of co-ordination present in the political economy.

These results suggest that the varieties-of-capitalism approach to institutional complementarities, built on the distinction between market and strategic co-ordination, has real merit. When complementary institutions are present across spheres of the political economy, rates of economic growth are higher. The institutional complementarities identified by this perspective appear to offer general efficiencies.

We conducted a number of robustness checks on these results, with particular attention to cases that might not be coded entirely accurately as noted above, namely Japan and Switzerland, and to cases where Kenworthy's index for co-ordination in wage-setting shows more than negligible movement over this time period, namely Denmark, Italy and New Zealand, as well as the United Kingdom, which showed some movement prior to $1980 .{ }^{49}$ We asked whether the exclusion of any of these cases, singly or together,

49 As a summary measure of variation over time, we calculated the percentage of years in which a country's wage co-ordination score was less than or equal to 1 point from its modal score during the 1971-97 period. For all countries except for Denmark, Italy and New Zealand, this was greater than 70 per cent. 


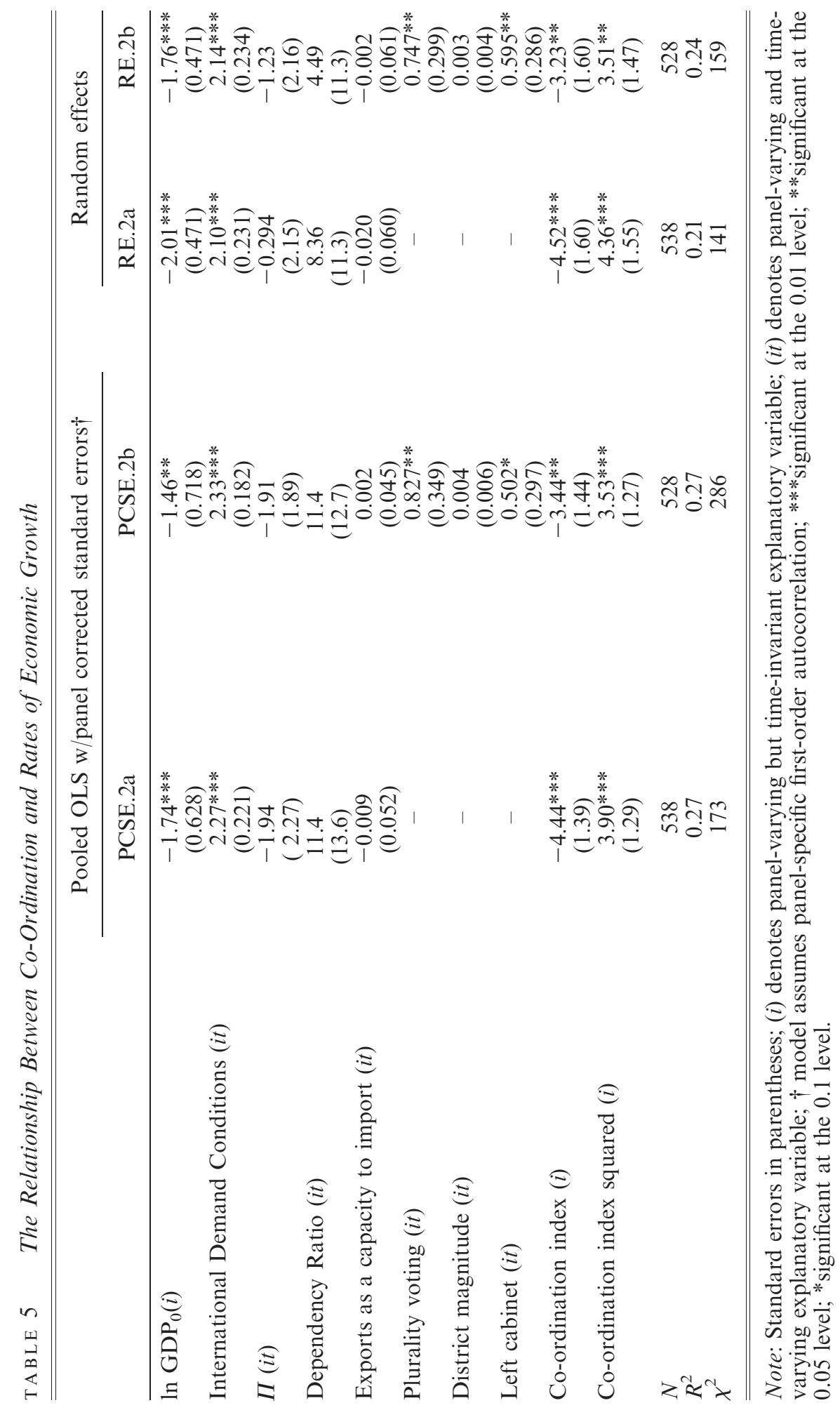


would affect our findings. Table 6 presents the results of these re-estimations. The table depicts the coefficient on the interaction between co-ordination in labour relations and coordination in corporate governance as well as the coefficients on the overall co-ordination index and its square for each combination of excluded cases. The table clearly suggests that our results do not depend on the inclusion of any one of these cases. Our findings are remarkably robust to the exclusion of particular cases, and even to the simultaneous exclusion of all potentially problematic cases. Outliers and unmeasured changes in coordination over time do not appear to pose serious threats to our conclusions.

\section{POLITICAL AND ECONOMIC ADJUSTMENT PATHS}

We conclude by turning to issues of institutional change. Although the historical record is generally supportive of the varieties-of-capitalism approach to comparative capitalism, a number of scholars have raised questions about the persistence of the cross-national differences identified by this analysis in the face of international pressures associated with 'globalization'. ${ }^{50}$ The varieties-of-capitalism literature addresses such issues. Some contributors to it explore the response of firms and governments to pressures for change, outlining how existing institutions structure processes of change. ${ }^{51}$ These formulations generate a set of predictions about national adjustment paths that we now examine empirically with a view to establishing whether the categories generated by the varietiesof-capitalism perspective remain a relevant typology.

\section{Economic Dynamics}

There are both economic and political sides to this matter. The principal economic issue is whether institutions that appear to have been complementary in previous decades continue to be complementary as secular developments, such as the shift from manufacturing to services, technological change and international liberalization, alter the economic challenges facing the developed democracies. ${ }^{52}$ These developments might alter the efficiencies available from existing combinations of institutions. If productivity growth is lower in services, for instance, the growth of that sector may undercut the efficiency gains available from systems of co-ordinated wage bargaining or of social protection that sustain high wage floors. ${ }^{53}$ Conversely, in epochs of rapid technological advance that increase the opportunities for radical innovation, the market-oriented complementarities of LMEs that lend themselves to this type of innovation may offer even higher returns

\footnotetext{
${ }^{50}$ Susanne Soederberg, Georg Menz and Philip G. Cerny, eds, Internalizing Globalization: The Rise of Neo-Liberalism and the Decline of National Varieties of Capitalism (Houndsmills, Hants.: Palgrave Macmillan, 2005); Jürgen Beyer and Martin Höpner, 'The Disintegration of Organised Capitalism: German Corporate Governance in the 1990s', West European Politics, 26 (2003), 179-198; Berger and Dore, eds, National Diversity and Global Capitalism; cf. Peter A. Hall, 'The Evolution of Varieties of Capitalism in Europe', in Hancké, Rhodes and Thatcher, eds, Beyond Varieties of Capitalism, pp. 39-88.

${ }^{51}$ Hall and Soskice, eds, Varieties of Capitalism.

${ }^{52}$ Peter A. Hall, 'The Political Economy of Adjustment in Germany', in Frieder Naschold, David Soskice, Bob Hancke and Ulrich Jurgens, eds, Okonomische Leitstungsfahigkeit und Institutionelle Innovation (Berlin: Sigma, 1997), pp. 293-317; Peter A. Hall, 'The Political Economy of Europe in an Era of Interdependence', in Kitschelt et al., eds, Change and Continuity in Contemporary Capitalism, pp. 135-63.

53 Torben Iversen and Anne Wren, 'Equality, Employment and Budgetary Restraint', World Politics, 50 (1998), 507-46; Viven Schmidt and Fritz Scharpf, Welfare and Work in the Open Economy: From Vulnerability to Competitiveness (Oxford: Oxford University Press, 2002).
} 


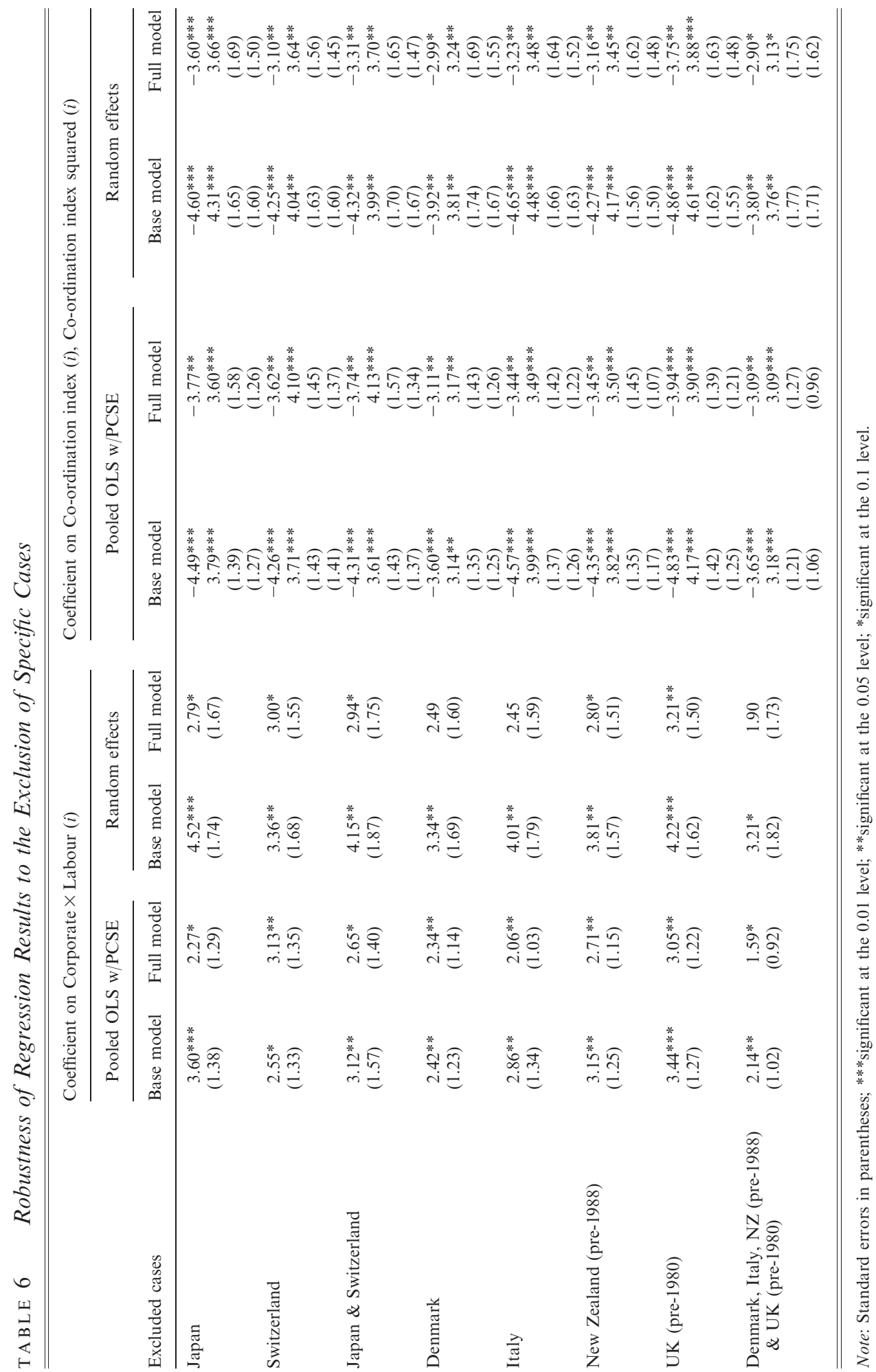


relative to those found in co-ordinated market economies which are better at incremental innovation. ${ }^{54}$ International integration could alter the value of an economy's comparative institutional advantages by improving access to production sites offering other kinds of complementarities. ${ }^{55}$

It is beyond the scope of this article to consider the effects of each of these developments on institutional complementarities. However, a summary impression can be formed by comparing the economic impact of particular combinations of institutions in more recent years with their impact in an earlier period. For this purpose, we re-estimate the models for the economic impact of co-ordination in labour relations and corporate governance, allowing the coefficient on the interaction of these variables to vary across two different time periods, 1971-84 and 1985-97. These estimations are used to test the following hypothesis:

HYPOTHESIS 7: Secular economic developments over the past two decades have not altered the efficiency of the institutional complementarities between labour relations and corporate governance posited by a varieties-ofcapitalism perspective.

If this hypothesis is correct, the coefficient on the interaction term between co-ordination in labour relations and corporate governance, $C_{i}^{L R} \cdot C_{i}^{C G}$, should be positive, statistically significant and of comparable magnitude across both periods. An $F$-test to evaluate the presence of structural change should fail to reject the null hypothesis of no difference across the two periods.

The results of the estimations are presented in Table 7. For both time periods, the coefficients on the interaction of co-ordination in corporate governance and labour relations are positive and statistically significant. Moreover, the difference in the magnitude of the coefficients across the time periods is miniscule, suggesting that the impact of institutional complementarities in these two spheres of the economy has not appreciably diminished with time. For both regressions, we performed an $F$-test, which indicates that we should not reject the null hypothesis of no difference across the two periods. This supports the hypothesis that secular economic developments in the 1980s and 1990s did not alter the basic complementarities identified by the varieties-of-capitalism perspective.

\section{Political Dynamics}

The varieties-of-capitalism literature also advances a particular view of the political dynamics associated with globalization. This view is built on the contention that the marketoriented institutions of LMEs encourage firms, holders of capital and workers to invest in switchable assets, whereas institutional support for strategic interaction in CMEs encourages higher levels of investment in specific assets. ${ }^{56}$ Fluid markets that facilitate the transfer of resources among uses enhance the returns to switchable assets in LMEs. In CMEs, better

\footnotetext{
${ }^{54}$ Hall and Soskice, 'Introduction'; Hall, 'The Political Economy of Adjustment in Germany'; David Soskice, 'Innovation Strategies of Companies, A Comparative Institutional Analysis of some CrossCountry Differences', in W. a M. D. Zapf, ed., Institutionenvergliech und Institutionendynamik (Berlin: WZB, 1994), pp. 271-89. On this point, our thinking has been influenced by conversations with Robert Fannion and Gavyn Davies.

55 Jeffry A. Frieden and Ronald Rogowski, 'The Impact of the International Economy on National Policies: An Analytical Overview', in Robert Keohane and Helen Milner, eds, Internationalization and Domestic Politics (New York: Cambridge University Press, 1996), pp. 25-47.

${ }^{56}$ Hall and Soskice, 'Introduction'; and Torben Iversen and David Soskice, 'An Asset Theory of Social Policy Preferences', American Political Science Review, 95 (2001), 875-93.
} 
TA B LE 7 The Impact on Economic Growth of Interaction Between Co-ordination in Labour Relations and Corporate Governance in 1971-84 and 1985-97

\begin{tabular}{|c|c|c|}
\hline & $\begin{array}{l}\text { Pooled OLS w/Panel } \\
\text { Corrected Standard } \\
\text { Errors } \dagger\end{array}$ & Random effects \\
\hline $\ln \mathrm{GDP}_{0}(i)$ & $\begin{array}{c}-1.97 * * * \\
(0.626)\end{array}$ & $\begin{array}{l}-2.21 * * * \\
(0.497)\end{array}$ \\
\hline International Demand & $2.50 * * *$ & $2.33 * * *$ \\
\hline Conditions (it) & $(0.21)$ & $(0.21)$ \\
\hline$\Pi(i t)$ & $\begin{array}{c}-3.58 \\
(2.39)\end{array}$ & $\begin{array}{c}-1.70 \\
(2.42)\end{array}$ \\
\hline Dependency Ratio (it) & $\begin{array}{r}2.37 \\
(13.9)\end{array}$ & $\begin{array}{r}5.55 \\
(11.4)\end{array}$ \\
\hline Exports as capacity to import (it) & $\begin{array}{r}-0.006 \\
(0.048)\end{array}$ & $\begin{array}{c}0.004 \\
(0.056)\end{array}$ \\
\hline Co-ordination in Corporate Governance $(i)$ & $\begin{array}{r}-1.49 \\
(1.26)\end{array}$ & $\begin{array}{c}-1.81 \\
(1.16)\end{array}$ \\
\hline Co-ordination in Labour Relations $(i)$ & $\begin{array}{l}-3.23^{* *} \\
(1.64)\end{array}$ & $\begin{array}{l}-3.20 * * \\
(1.56)\end{array}$ \\
\hline Corporate $\times$ Labour $(i) \times I[$ period 1971-84] & $\begin{array}{l}3.91 * * * \\
(1.23)\end{array}$ & $\begin{array}{l}4.59 * * * \\
(1.70)\end{array}$ \\
\hline Corporate $\times$ Labour $(i) \times I[$ period 1985-97] & $\begin{array}{l}3.44 * * * \\
(1.21)\end{array}$ & $\begin{array}{l}4.07 * * \\
(1.69)\end{array}$ \\
\hline $\begin{array}{l}N \\
R^{2}\end{array}$ & $\begin{array}{r}538 \\
0.31\end{array}$ & $\begin{array}{l}538 \\
0.25\end{array}$ \\
\hline \multirow[t]{3}{*}{$\begin{array}{l}\text { Test of structural change in the effect of } \\
\text { interaction between co-ordination in } \\
\text { corporate governance and labour } \\
\text { relations }\end{array}$} & $\begin{array}{l}H_{0}: \beta \text { (interaction } \\
\quad 1971-84)=\beta(\text { interac- } \\
\quad \text { tion } 1985-97)\end{array}$ & $\begin{array}{l}H_{0}: \beta(\text { interaction } \\
\quad 1971-84)=\beta(\text { interac- } \\
\quad \text { tion } 1985-97)\end{array}$ \\
\hline & $\begin{array}{l}H_{\mathrm{A}}: \beta(\text { interaction } \\
\quad 1971-84) \neq \beta(\text { interac- } \\
\quad \text { tion } 1985-97)\end{array}$ & $\begin{array}{l}H_{\mathrm{A}}: \beta(\text { interaction } \\
\quad 1971-84) \neq \beta(\text { interac- } \\
\text { tion } 1985-97)\end{array}$ \\
\hline & $\begin{array}{l}F \text {-stat. }=0.443 \\
\operatorname{Pr}\left(1.52, v_{1}=1\right. \\
\left.\quad v_{2}=527\right)=0.506\end{array}$ & $\begin{array}{l}F \text {-stat. }=0.505 \\
\operatorname{Pr}\left(0.91, v_{1}=1\right. \\
\left.\quad v_{2}=527\right)=0.478\end{array}$ \\
\hline
\end{tabular}

Note: Standard errors in parentheses; $(i)$ denotes panel-varying but time-invariant explanatory variable; (it) denotes panel-varying and time-varying explanatory variable; $\dagger$ model assumes panel-specific first-order autocorrelation; ***significant at the 0.01 level; **significant at the 0.05 level; *significant at the 0.1 level.

institutional support for the formation of credible commitments reduces the risks of investing in co-specific assets whose value depends on the co-operation of other actors.

These patterns of investment are significant because each generates a different politics. In the face of an exogenous shock threatening returns to existing activities, holders of mobile assets will be tempted to 'exit' those activities to seek higher returns elsewhere, while holders of specific assets face higher incentives to exercise 'voice' in defence of existing activities. ${ }^{57}$ The argument is analogous to the distinction drawn between a Hecksher-Ohlin world, where factors are mobile and shifts in relative prices (of the sort

${ }^{57}$ Albert Hirschman, Exit, Voice, and Loyalty (Cambridge, Mass.: Harvard University Press, 1964). 
associated with increasing economic openness) generate conflict between the holders of basic factors, such as capital and labour, and a Ricardo-Viner world of sector-specific factors where shifts in relative prices inspire inter-sectoral conflicts that unite employers and workers in defence of sectoral interests. ${ }^{58}$

From this perspective, the varieties-of-capitalism literature argues that the political response to contemporary economic challenges will vary across liberal and co-ordinated market economies. In LMEs, the response will be market-oriented. When returns to existing activities are threatened, holders of mobile assets, such as workers with general skills or owners of capital on fluid equity markets, will move their assets to new activities. Many will be interested, therefore, in rendering markets even more fluid and governments may be responsive to them. Moreover, where nations respond to shocks by relying on markets to adjust prices and wages, substantial shifts in the distribution of income are likely to occur, reflecting the advantages of those with market power.

In CMEs, by contrast, the varieties-of-capitalism perspective expects economic challenges to inspire a political response mediated by higher levels of asset specificity. When returns to existing activities are threatened, holders of specific assets, such as workers with industryspecific skills and owners of enterprises deeply-invested in co-specific assets, will find it difficult to shift to new activities. As a result, they will be less inclined to favour deregulatory initiatives that increase market competition and more inclined to demand institutional support for existing activities. The result is likely to be a much slower process of liberalization and a politics that unites workers and employers in 'cross-class' coalitions of sectoral defence. ${ }^{59}$

These postulates about political dynamics suggest that economic shocks will produce different institutional outcomes in LMEs and CMEs. Although all capitalist economies use markets to adjust and international integration automatically renders some markets more competitive, this analysis anticipates more rapid deregulation in LMEs, where there should be more political support for it, compared to CMEs, where cross-class coalitions support existing regulatory regimes. The perspective anticipates change in all countries, including some liberalization in CMEs, but institutional adjustment paths that diverge across different types of political economies. ${ }^{60}$

In order to assess whether that account accurately describes the response to recent challenges, we examine a number of indicators beginning with levels of inequality. If LMEs respond to economic challenges by relying more heavily on competitive markets to reset wages and prices, we should see more rapid increases in income inequality there in response to the recent experiences of globalization. Figure 6 shows that this has indeed been the pattern. ${ }^{61}$

58 Michael J. Hiscox, 'Class versus Industry Cleavages: Inter-Industry Factor Mobility and the Politics of Trade', International Organization, 55 (2001), 1-46; Frieden and Rogowski, 'The Impact of the International Economy on National Policies'; James Alt, Jeffry Frieden, Michael Gilligan, Dani Rodrik and Ronald Rogowski, 'The Political Economy of International Trade: Enduring Puzzles and an Agenda for Inquiry', Comparative Political Studies, 29 (1996), 689-717.

59 Peter Swenson, 'Bringing Capital Back In, or Social Democracy Reconsidered: Employer Power, Cross-Class Alliances and Centralization of Industrial Relations in Denmark and Sweden', World Politics, 43 (1991), 513-44; Kathleen Thelen and Ikuo Kume, 'The Effects of Globalization on Labour Revisited: Lessons from Germany and Japan', Politics and Society, 27 (1999), 477-505; Stewart Wood, 'Employer Preferences, State Power and Labour Market Policy in Germany and Britain', in Hall and Soskice, eds, Varieties of Capitalism, pp. 247-74.

${ }^{60}$ Hall, 'The Evolution of Varieties of Capitalism in Europe'.

61 For the empirical analysis in this section of the article, we adopt the classification of political economies that Hall and Soskice use, terming those that they do not classify definitively as liberal or 


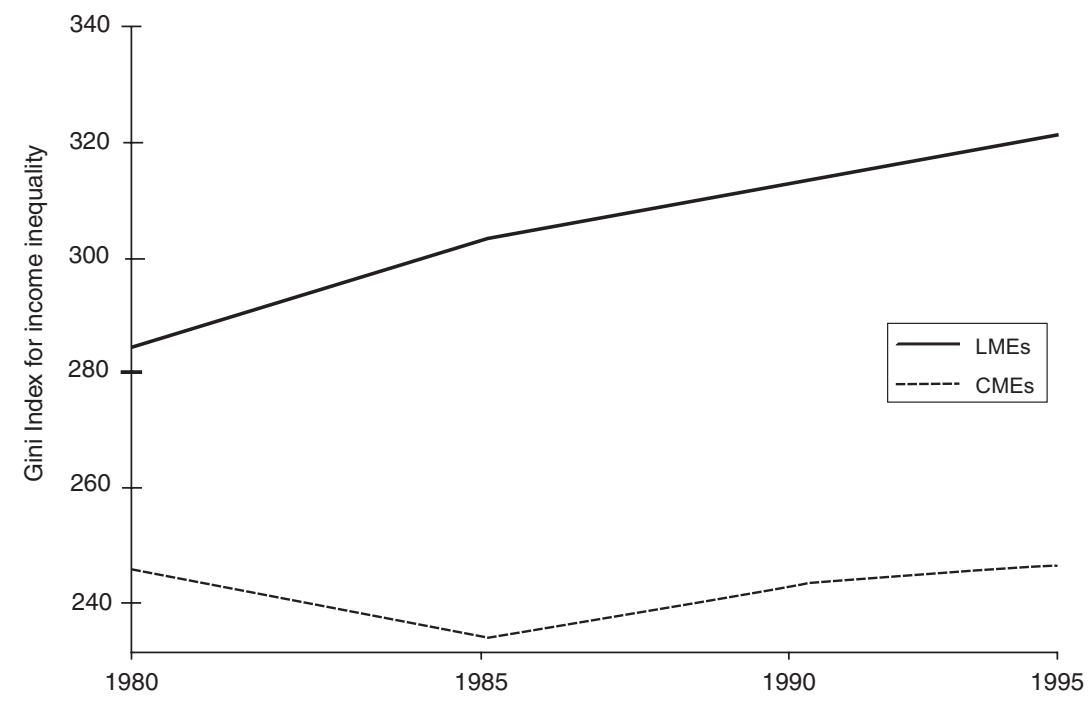

Fig. 6. Changes in inequality in disposable income in liberal and co-ordinated market economies, 1980-95 Source: Luxembourg Income Study.

To what extent have the institutional differences that underpin different modes of coordination narrowed in the face of globalization? To form an assessment, we assemble indicators for the character of institutional practices in six spheres relevant to the varietiesof-capitalism arguments. The observations are drawn from the 1980s and the 1990s, including the early 2000s where data was available, and they are reported in Table 8. We distinguish between LMEs, CMEs and a third group of South European nations termed here 'mixed market economies' because they are not definitively classified into the other two categories by the varieties-of-capitalism literature and cluster distinctively in Figure 2. ${ }^{62}$

The figures presented in Table 8 display substantial differences between CMEs and LMEs during the 1980s of the sort associated with different types of co-ordination. Of most interest, however, are the changes taking place from 1980 to the early 2000s. Did these differences between LMEs and CMEs narrow in ways that reflect convergence on a single economic model? Table 8 shows that the direction of institutional reform is often similar across the two types of political economies. But, when variation in the pace and extent of movement is considered, substantial differences in the institutional practices of CMEs and LMEs remain. Although the locus of wage bargaining has moved downwards in most of these economies, for instance, the proportion of workers covered by a collective agreement declined much more rapidly in LMEs than in CMEs. In the realm of social protection, social spending has crept upwards and employment protection has declined, but differences between the two types of economies remain pronounced. While LMEs sharpened market mechanisms, many CMEs cushioned their citizens against the effects of

\footnotetext{
(F'note continued) co-ordinated market economies, mixed market economies. Portugal, Spain, France and Italy are in the latter category. See Hall and Soskice, 'Introduction'.

${ }^{6}$ As labelled here, mixed market economies include those that fall clearly below the regression line on the right-hand side of Figure 2, i.e. Spain, Portugal, Italy and France.
} 
TABLE $8 \quad$ Patterns of Institutional Practices in Different Types of Political

Economies from the 1980s to the Early 2000s

\begin{tabular}{|c|c|c|c|c|c|c|c|c|c|}
\hline & \multicolumn{3}{|c|}{ CMEs } & \multicolumn{3}{|c|}{ LMEs } & \multicolumn{3}{|c|}{ MMEs } \\
\hline & $1980 \mathrm{~s}$ & $1990 \mathrm{~s}$ & $\% \Delta$ & $1980 \mathrm{~s}$ & $1990 \mathrm{~s}$ & $\% \Delta$ & $1980 \mathrm{~s}$ & $1990 \mathrm{~s}$ & $\% \Delta$ \\
\hline \multicolumn{10}{|l|}{ Industrial relations } \\
\hline Trade-union density & 49 & 51 & 4 & 34 & 32 & -6 & 30 & 32 & 7 \\
\hline Bargaining coverage & 76 & 75 & -1 & 58 & 48 & -17 & 78 & 84 & 8 \\
\hline Bargaining level & 4.2 & 4.0 & -5 & 1.9 & 1.8 & -5 & 2.2 & 2.7 & 23 \\
\hline \multicolumn{10}{|l|}{ Social protection } \\
\hline Employment protection & 2.6 & 2.0 & -23 & 0.7 & 0.7 & 0 & 3.6 & 3.3 & -8 \\
\hline Benefit entitlements & 32.6 & 35.5 & 9 & 24.4 & 24.1 & -1 & 19 & 28.4 & 50 \\
\hline Social spending/GDP & 21 & 25 & 19 & 15 & 18 & 20 & 16 & 24 & 50 \\
\hline \multicolumn{10}{|l|}{ Labour market flexibility } \\
\hline Part-time employment & 16 & 18 & 13 & 16 & 20 & 25 & 8 & 10 & 25 \\
\hline Avg. hours worked & 1,722 & 1,553 & -10 & 1,837 & 1,732 & -6 & 1,943 & 1,705 & -12 \\
\hline Income inequality & 0.24 & 0.26 & 8 & 0.28 & 0.33 & 18 & 0.31 & 0.32 & 1 \\
\hline \multicolumn{10}{|l|}{ Firm structure } \\
\hline Average job tenure & 9.5 & 9.9 & 4 & 7.3 & 7.3 & 0 & 10.7 & 9.6 & -11 \\
\hline CEO compensation & 8.5 & 9.8 & 15 & 10.3 & 17.6 & 29 & 9.7 & 15.3 & 37 \\
\hline \multicolumn{10}{|l|}{ Corporate governance } \\
\hline Stock mkt capitalization & 28 & 69 & 146 & 47 & 79 & 68 & 8 & 37 & 363 \\
\hline Debt/equity ratio & 2.8 & 1.9 & -40 & 0.60 & 0.89 & 48 & 2.3 & 2.2 & -4 \\
\hline \multicolumn{10}{|l|}{ Earnings and employment } \\
\hline Real earnings & 0.75 & 1.26 & 68 & 0.45 & 0.78 & 74 & 1.13 & 0.93 & -18 \\
\hline Unit labour costs & 73.4 & 99.4 & 44 & 67.6 & 97.4 & 35 & 54.4 & 101.8 & 87 \\
\hline Total employment & 69 & 70 & 1 & 65 & 64 & -2 & 57 & 57 & 0 \\
\hline
\end{tabular}

Note: The table compares average figures for 1980-89 with average figures for 1990-2002 or latest date available. For variable descriptions and sources, see Appendix Table A2. LMEs include: USA, UK, Canada, Australia, NZ, Ireland. CMEs include: Germany, Japan, Austria, Sweden, Norway, Denmark, Finland, Netherlands, Belgium, Switzerland. MMEs include: Portugal, Spain, France, Italy, Greece, but sample sizes vary with data availability. $\% \Delta=$ percentage change.

market adjustment with increases in benefit entitlements. ${ }^{63}$ In the labour market, increases in part-time employment indicate a general movement towards labour market flexibility, but LMEs increase income inequality and CMEs reduce hours of work faster than their counterparts.

Especially intriguing are indicators for the institutional practices associated with firm strategy and finance. Here, much has been made of changes in CMEs that seem to reflect convergence on the practices of LMEs. However, these figures tell a more nuanced story. In CMEs, the ratio of the compensation of chief executive officers to that of manufacturing workers and the size of stock markets increased, but the analogous increases

63 However, some of these entitlements are being gradually reduced again. See Elmar Rieger and Stephan Leibfried, Limits to Globalization: Welfare States and the World Economy (Cambridge: Polity Press, 2003). 
in LMEs were also substantial, leaving large gaps in institutional practices between the two types of political economies, which is also apparent in the debt-to-equity ratios of non-financial enterprises. The figures for earnings and employment tell a classic story of different adjustment paths. Strategically co-ordinated wage bargaining pushed real earnings up in CMEs at rates that outpaced those in LMEs, but effective forms of co-ordination in the workplace and high levels of investment kept the increase in unit labour costs in CMEs roughly commensurate with that of LMEs.

On balance, we read these figures as suggesting that institutional practices did not converge dramatically in the decades after 1980. Modest efforts were made to improve the flexibility of CMEs, including some liberalization of labour and capital markets, but the pace of movement was slow enough to leave significant differences in institutional practices across the two types of political economies. The absence of more convergence in the face of intense pressures during the 1980s and 1990s suggests that the distinctions drawn by the varieties-of-capitalism literature may be relevant for years to come.

\section{CONCLUSION}

We entered this project uncertain about whether we could find indicators for the relevant variables and what the tests of the hypotheses would reveal. We leave it impressed with the uniformity of the results. The weight of the evidence suggests that the varietiesof-capitalism literature captures important differences between political economies. The concepts of market-oriented and strategic co-ordination do seem to reflect an underlying dimension distinguishing practices across countries in the spheres of labour relations and corporate governance. The contention that institutional complementarities operate across these two spheres of the political economy is also borne out by the evidence. Persistent cross-national differences in institutional practices in the face of intense pressures for convergence, suggest that, despite some liberalization in CMEs, the distinctions central to the varieties-of-capitalism perspective are likely to be of continuing value.

Our findings about complementarities have especially important implications for reform proposals now being considered in the developed world. The deregulation of labour markets is a popular cause. However, our evidence suggests that labour-market deregulation is likely to produce large economic gains only in nations where financial markets are correspondingly fluid (see Figure 4). Otherwise, the gains in growth may be relatively small. Many nations have come under pressure from international agencies or global enterprises to increase competition in markets for corporate governance. However, our estimates suggest that such steps may have positive effects only where labour markets are also highly fluid.

The broader lesson is that those seeking to understand the effects of institutional change should pay careful attention to the potential for institutional complementarities across spheres of the political economy. Most proposals to reform labour or capital markets are based on estimates of the effects of such reforms that consider data only for the sphere being reformed. If the distribution of institutions across national cases were random, estimates generated from cross-national data of this sort might produce accurate results. But our evidence indicates that this distribution is far from random: nations with particular types of institutions in one sphere tend to have particular types of institutions in other spheres. As a result, models that do not take interaction effects across institutional spheres into account may attribute to one set of institutions effects that are actually generated by interaction among several sets of institutions. 
This is a research agenda rather than a counsel of despair that finds complementarities everywhere. Although there are undoubtedly other ones, the varieties-of-capitalism literature presents propositions about particular complementarities that can be examined more closely. The range of institutional indicators available for doing so is growing, as is the evidence that such analyses can be fruitful. ${ }^{64}$ In broad terms, this analysis lends weight to the theoretical perspectives advanced in the varieties-of-capitalism literature. It suggests that the concepts of market-oriented and strategic co-ordination can illuminate the operation of many developed political economies and contribute important insights to understanding their politics and economic performance.

APPENDIX TABLE A $1 \quad$ Variable Descriptions for the Growth Regressions

\begin{tabular}{|c|c|c|}
\hline Variable & Definition & Source \\
\hline$Y_{i t}$ & $\begin{array}{l}\text { Growth rate of real GDP per capita (constant } \\
\text { prices: chain series). }\end{array}$ & Penn World Table 6.1 \\
\hline $\operatorname{lnGDP}_{i}$ & $\begin{array}{l}\text { Log GDP per capita in } 1971 \text { calculated using real } \\
\text { GDP per capita (constant prices: chain series). }\end{array}$ & Penn World Table 6.1 \\
\hline $\operatorname{Int}_{i t}$ & $\begin{array}{l}\text { Average rate of growth for the entire sample in each } \\
\text { year weighted by a country's trade openness. }\end{array}$ & $\begin{array}{l}\text { Openness: OECD Statistical } \\
\text { Compendium 2006, vol.1 }\end{array}$ \\
\hline$\pi_{i t}$ & $\begin{array}{l}\text { Rate of growth of inflation (as measured by the } \\
\text { CPI). }\end{array}$ & $\begin{array}{l}\text { World Bank, World Development } \\
\text { Indicators }\end{array}$ \\
\hline $\operatorname{Exp}_{i t}$ & $\begin{array}{l}\text { Percentage change in exports as a capacity to } \\
\text { import (constant LCU) weighted by trade } \\
\text { openness. Exports as a capacity to import equals } \\
\text { the current price value of exports of goods and } \\
\text { services deflated by the import price index. }\end{array}$ & $\begin{array}{l}\text { World Bank, World Development } \\
\text { Indicators }\end{array}$ \\
\hline$D_{i t}$ & $\begin{array}{l}\text { Percentage change in the dependency ratio (number } \\
\text { of individuals under } 15 \text { and older than } 65 \text { as a } \\
\text { percentage of working age population). }\end{array}$ & $\begin{array}{l}\text { World Bank, World Development } \\
\text { Indicators }\end{array}$ \\
\hline$P L U_{i t}$ & $\begin{array}{l}1 \text { if majority of representatives in lower house are } \\
\text { elected by plurality voting, } 0 \text { otherwise. }\end{array}$ & $\begin{array}{l}\text { Database of Political Institutions, } \\
\text { World Bank Institute, http:// } \\
\text { www.worldbank.org/wbi }\end{array}$ \\
\hline$M A G_{i t}$ & Average district magnitude in the lower chamber. & Database of Political Institutions \\
\hline Leftcab $_{i t}$ & $\begin{array}{l}\text { Left party cabinet portfolios as proportion of total } \\
\text { cabinet portfolios. }\end{array}$ & $\begin{array}{l}\text { Duane Swank's Comparative } \\
\text { Parties Data Set (http:// } \\
\text { www.marquette.edu/polisci/ } \\
\text { Swank.htm) }\end{array}$ \\
\hline
\end{tabular}

${ }^{64}$ Amable et al., 'How Do Financial Markets Affect Industrial Relations?'; Ernst, 'Financial Systems, Industrial Relations, and Industry Specialization'; Nicoletti, Scarpetta and Boylaud, 'Summary Indicators of Product Market Regulation with an Extension to Employment Protection Legislation'; LaPorta et al., 'Law and Finance'; Lane Kenworthy, In Search of National Economic Success (Thousand Oaks, Calif.: Sage, 1995). 
APPEndix TABLE A2 Variable Descriptions for Table 8

\begin{tabular}{|c|c|c|}
\hline Variable & Description & Source \\
\hline $\begin{array}{l}\text { Trade-union } \\
\text { density }\end{array}$ & $\begin{array}{l}\text { Union membership as percentage of } \\
\text { labour force: } 1980-89 \text { v. } 1990-2002 \text {. }\end{array}$ & $\begin{array}{l}\text { Comparative Welfare States Data Set } \\
\text { 2004, OECD Employment Outlook } \\
\text { 1997, European Industrial } \\
\text { Relations Observatory On-line }\end{array}$ \\
\hline $\begin{array}{r}\text { Bargaining } \\
\text { coverage }\end{array}$ & $\begin{array}{l}\text { Percentage of labour force covered by } \\
\text { collective bargaining: } 1980,1985 \text { v. } \\
\text { 1990, 1994, 2000, 2001, 2002. }\end{array}$ & $\begin{array}{l}\text { OECD Employment Outlook 1994, } \\
\text { 1997, European Industrial } \\
\text { Relations Observatory On-line }\end{array}$ \\
\hline Bargaining level & $\begin{array}{l}\text { Degree of centralization in wage } \\
\text { bargaining: } 1980-89 \text { v. } 1990-2000 .\end{array}$ & $\begin{array}{l}\text { Comparative Welfare States Data Set } \\
\text { 2004, OECD Employment Outlook } \\
\text { 1997, European Industrial } \\
\text { Relations Observatory On-line }\end{array}$ \\
\hline $\begin{array}{l}\text { Employment } \\
\text { protection }\end{array}$ & $\begin{array}{l}\text { Strictness of legislation for regular } \\
\text { and temporary contracts: late } \\
1980 \text { s v. late } 1990 \text { s. }\end{array}$ & OECD Employment Outlook 1997 \\
\hline $\begin{array}{l}\text { Benefit } \\
\text { entitlements }\end{array}$ & $\begin{array}{l}\text { Gross replacement rate for } \\
\text { unemployment benefit averaged } \\
\text { over earning levels and family } \\
\text { situations: } 1981,1983,1985,1987, \\
1989 \text { v. } 1991,1993,1995,1997,1999 .\end{array}$ & $\begin{array}{l}\text { OECD Benefits and Wages } \\
\text { Indicators } 2002 \text {. }\end{array}$ \\
\hline $\begin{array}{l}\text { Social spending/ } \\
\text { GDP }\end{array}$ & $\begin{array}{l}\text { Public social expenditure as a } \\
\text { percentage of GDP: } 1980 \text { v. } 2003 \text {. }\end{array}$ & OECD Factbook 2007 \\
\hline $\begin{array}{l}\text { Part-time } \\
\text { employment }\end{array}$ & $\begin{array}{l}\text { Percentage of labour force employed } \\
\text { less than } 30 \text { hours per week in their } \\
\text { main job: } 1980-89 \text { v. } 1990-2002 \text {. }\end{array}$ & OECD Labour Force Statistics 2003 \\
\hline $\begin{array}{l}\text { Average hours } \\
\text { worked }\end{array}$ & $\begin{array}{l}\text { Hours per year worked per person } \\
\text { in employment: } 1980 \text { v. } 2005 .\end{array}$ & OECD Factbook 2007 \\
\hline Income inequality & $\begin{array}{l}\text { Gini Coefficient for disposable } \\
\text { income: year closest to } 1980 \mathrm{v} . \\
\text { most recent available year. }\end{array}$ & $\begin{array}{l}\text { Luxembourg Income Data Study } \\
\text { Key Figures. }\end{array}$ \\
\hline $\begin{array}{l}\text { Average job } \\
\text { tenure }\end{array}$ & $\begin{array}{l}\text { Average number of years employed } \\
\text { with same firm: } 1980,1985 \text {, } \\
1989 \text { v. } 1990,1991,1995 .\end{array}$ & $\begin{array}{l}\text { OECD, Employment Outlook 1993, } \\
1997 .\end{array}$ \\
\hline $\begin{array}{l}\text { CEO } \\
\text { compensation }\end{array}$ & $\begin{array}{l}\text { Ratio of total CEO compensation and } \\
\text { benefits to that of manufacturing } \\
\text { operatives: } 1984 \text { v. } 1996 .\end{array}$ & $\begin{array}{l}\text { John M. Abowd and David S. } \\
\text { Kaplan, 'Executive Compensation, } \\
\text { Six Questions that Need } \\
\text { Answering', National Bureau of } \\
\text { Economic Research Working } \\
\text { Paper No. 7124, May } 1999 .\end{array}$ \\
\hline $\begin{array}{l}\text { Stock market } \\
\text { capitalization }\end{array}$ & $\begin{array}{l}\text { Ratio of stock market capitalization } \\
\text { to GDP: } 1980-89 \text { v. } 1990-2001 .\end{array}$ & World Bank Online Database \\
\hline Debt/equity ratio & $\begin{array}{l}\text { Ratio of debt to equity for non- } \\
\text { financial enterprises: } 1980 / 85 \mathrm{v} \text {. } \\
1992 / 93 \text {. }\end{array}$ & $\begin{array}{l}\text { OECD Economies at a Glance: } \\
\text { Structural Indicators } 1996\end{array}$ \\
\hline Real earnings & $\begin{array}{l}\text { Year to year percentage change in real } \\
\text { hourly earnings in manufacturing: } \\
1980-89 \text { v. } 1990-2000 .\end{array}$ & OECD Historical Statistics 2001 \\
\hline Unit labour costs & $\begin{array}{l}\text { Wages, salaries, employer contributions } \\
\text { per unit of output: } 1980-89 \mathrm{v} \text {. } \\
1990-2000 \text {. }\end{array}$ & OECD STAN Indicators database \\
\hline Total employment & $\begin{array}{l}\text { Total employment as percentage } \\
\text { of population aged } 15 \text { to } 64 \text { : } \\
1980-89 \text { v. } 1990-2000 \text {. }\end{array}$ & OECD Historical Statistics 2001 \\
\hline
\end{tabular}

